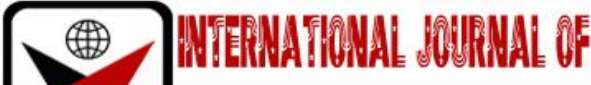

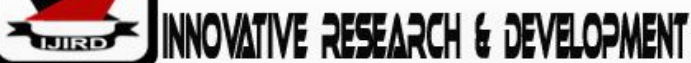

ISSN 2278 - 0211 (Online)

\section{Real-Time Production of Synthetic Gasoline, Kerosene or Diesel from Methane in the Flare Stream Associated Gas in Nigeria}

\author{
Dr. Azunna I.B. Ekejiuba \\ Senior Lecturer, Department of Petroleum Engineering, \\ Federal University of Technology, Owerri, Nigeria
}

\begin{abstract}
:
Any gas can be liquefied at atmospheric pressure if it is cooled sufficiently. Fundamentally, every gas has its critical temperature, above which it cannot be liquefied by increase of pressure, but if it is cooled below its critical temperature, it liquefies if pressure is gradually increased e.g. the critical temperature for oxygen $(-181.1 \mathrm{oF}$ or $-119 \mathrm{oC})$, nitrogen $(-232.4 \mathrm{oF}$ or $-147 \mathrm{oC})$, hydrogen $(-399.8 \mathrm{oF}$ or $-240 \mathrm{oC})$, methane $(-116.63 \mathrm{oF}$ or $-82.3 \mathrm{oC})$ et cetera. On the other hand, any gas which has a critical temperature above room temperature can be liquefied by pressure alone e.g. ammonia ( $270.3 \mathrm{oF}$ or $132.4 \mathrm{oC}$ ), chlorine ( $291 \mathrm{oF}$ or $144.0 \mathrm{oC}$ ), carbon dioxide ( $87.9 \mathrm{oF}$ or $31.1 \mathrm{oC}$ ), hydrogen chloride ( $124.5 \mathrm{oF}$ or $51.4 \mathrm{oC}$ ), hydrogen sulfide (212.7 oF or $100.4 \mathrm{oC}$ ) and hydrogen dioxide (315.5 oF or $157.5 \mathrm{oC}$ ). This study on the real-time (direct/ single-step) production of synthetic gasoline, kerosene or diesel from methane in the flare stream associated gas in Nigeria, stated the various sources of methane, the hydrocarbon components of gasoline, kerosene and diesel, the five practical ways of transporting methane (natural gas) to consumer (i.e. by pipeline, CNG, LNG, NGH and GTL) and explained the relation of liquids to gases and solids.

Theoretically the investigation reviewed the concept of gas liquefaction from the fundamental gas laws and their application in various processes (mechanical refrigeration, turbo-expander cycle, joule-thomson cycle and fischer-tropsch 'FT') as well as distinguished between the various types of catalysts, their mechanism of catalytic reactions (homogeneous and heterogeneous) and their ability to generate radicals/ hydrocarbon building blocks. Also, the paper reviewed the chemical reaction mechanism of the existing indirect/direct GTL models and subsequently proposed four single-step GTL processes based on the synergy/ synthesis (i.e. combined application or effects) of various scientific fundamentals, including the direct chemical conversion of CNG/ LNG to GTL.

The study estimates that 1,570.7500 barrels (8,819.483 cu. ft.) equivalent to $65,971.5$ gallons or 251,320 liters of synfuel products plus 11.5 MW electricity could be obtainable daily from a 20 MMscfd flare line made up of $78.5375 \%$ methane.
\end{abstract}

Keywords: Direct GTL processes, methane, single-step synfuel production, synthetic gasoline

\section{Introduction}

Methane, the simplest alkane hydrocarbon, was scientifically identified by Alessandra Volta, an Italian physicist, in 1776 after reading a paper written by Benjamin Flanklin about 'flammable air' (Wikipedia-Methane). It is a tetrahedral molecule with four equivalents $\{\mathrm{C}-\mathrm{H}$ bonds $\}$, figure 1, i.e. it is a molecule in which one carbon atom is bound to four hydrogen atoms by strong chemical bonds (Shad and Durr, 2007). Under normal conditions of temperature and pressure (i.e. standard atmospheric pressure and temperature) methane is a colorless, odorless gas. In general methane is very stable (Encyclopaedia Britannica - methane) and has one of the strongest bonds among hydrocarbons; hence its chemical reactivity is very low. The typical molecular model of methane is represented with either space-filling or ball-and-stick arrangement, with all bond angles $109.5^{\circ}$, as shown in figure 2 . 


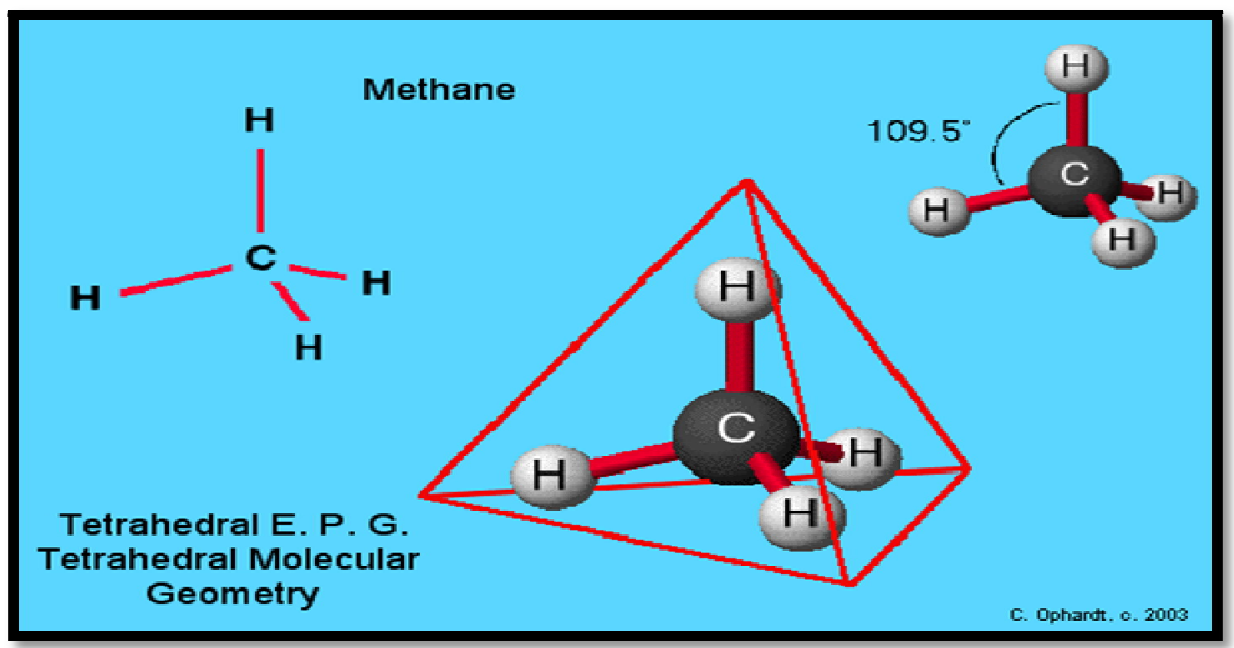

Figure 1: Four Equivalent C-H Bonds of Methane.

Source: Adapted From Image of Tetrahedral Methane

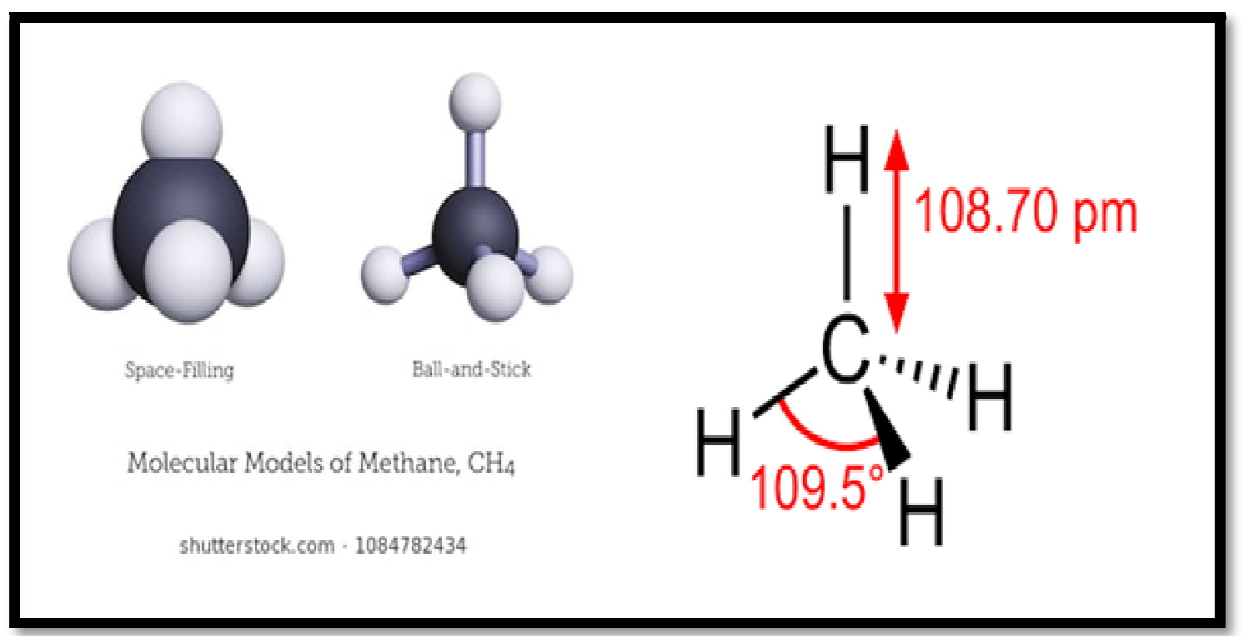

Figure 2: Typical Molecular Models of Methane

Source: Adapted from image of Methane

\subsection{Sources of Methane}

The main sources of methane include; natural gas (associated and non-associated); naturally occurring gas hydrates (methane clathrates in the ocean floor, abiotic methane in the ocean floor, permafrost hydrates), geo-pressured reservoirs, volcanoes and substitute natural gas/ synthetic natural gas (SNG) from gas in tight sands and shale's, coal seams (coal-bed-methane), oil shale, hydrocarbon liquids, hydrogen, organic wastes from biomass called biogas \{i.e. fermentation (anaerobic bacteria decomposition of vegetable matter under water, wetland) including manure, waste water sludge, municipal solid waste 'landfills' \}, termites digestive processes and atmospheric methane (WikipediaMethane; Encyclopaedia Britannica-methane; Ikoku, 1980). Figure 3, shows the recyclable nature of methane from landfills or digesters.

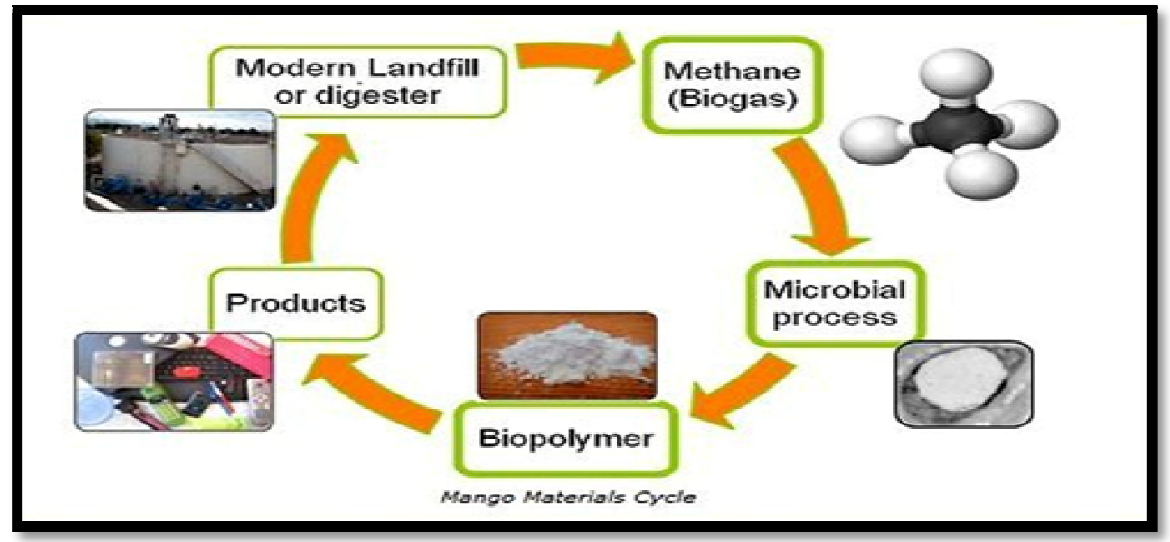

Figure 3: From Methane to Plastic to Methane, Without Waste

Source: Adapted from Foster, 2012 


\subsection{Hydrocarbon Components of Gasoline (Petrol), Kerosene and Diesel (Gas Oil)}

In general, the petroleum fuels are a group of hydrocarbons refined and modified from the crude oil, and include more than 100 kinds of aliphatic and aromatic hydrocarbons. This includes petroleum gas (LNG and LPG), gasoline, kerosene, diesel (light oil and heavy oil), et cetera. The constituents of automobile gasoline, purified kerosene and automobile light oil for a diesel engine are the $\mathrm{C}_{5}-\mathrm{C}_{20}$ hydrocarbons.

The typical gasoline consists of a mixture of paraffins (alkanes), cycloalkanes (naphthenes), and olefins (alkenes), hydrocarbons with between 5 and 10 carbon atoms per molecule (Wikipedia- Gasoline), figures 4 and 5. Kerosene is composed of carbon chains that typically contain between 10 and 16 carbon atoms per molecule(Wikipedia- Kerosene ), figure 5.Petroleum-derived diesel is composed of about 75\% saturated hydrocarbons primarily paraffins including (normal \& iso), and cycloparaffins\}, and 25\% aromatic hydrocarbons (including naphthalenes and alkylbenzenes), (Wikipedia- Diesel fuel ) with between 14 and 18 carbon atoms per molecule, figure 5.

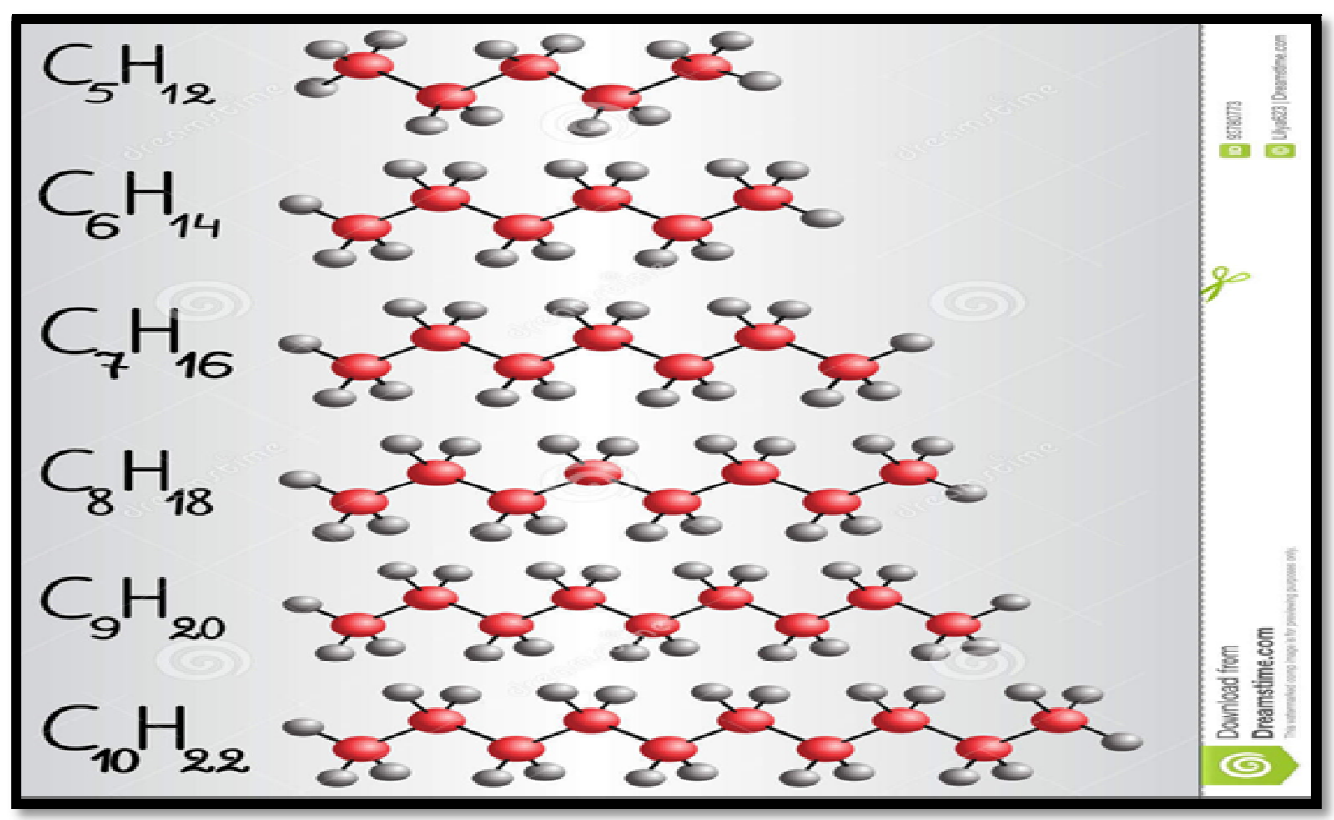

Figure 4: Hydrocarbons That Make up Gasoline Source: Adapted from images of Methane

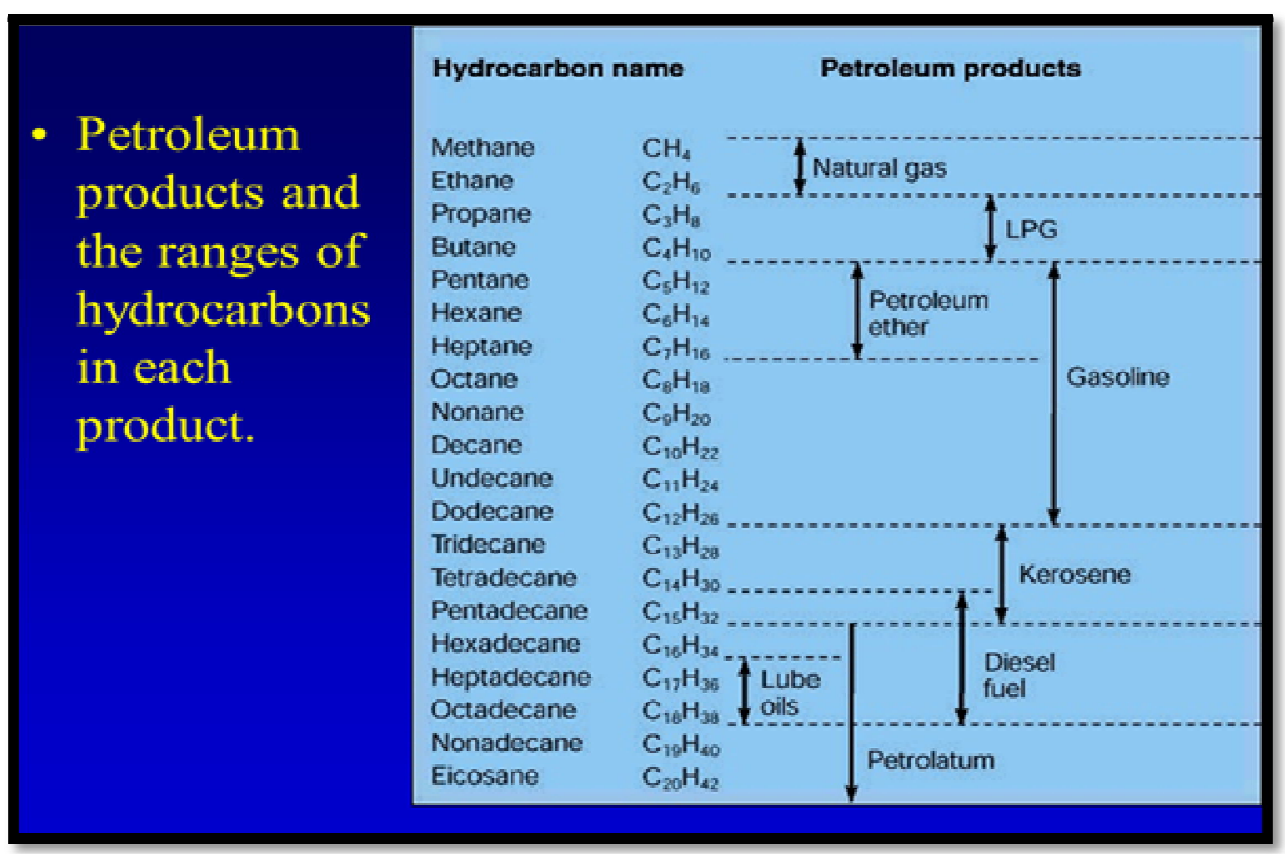

Figure 5: Basic Petroleum Refinery Products

Source: Adapted from Images of the Hydrocarbon Chemistry

In contrast, synthetic liquid fuels (synfuels) are liquid fuels (such as gasoline, kerosene, diesel, et cetera) which are produced from other source apart from petroleum crude oil (i.e. instead of refining crude oil). They are liquid or gaseous fuels obtained (extracted or derived) from either gasification of solid earth material feedstock that are rich in hydrocarbons (i.e. compounds containing hydrogen and carbon). In principal, synfuels can be produced from substitute/ synthetic natural gas (S.N.G.) otherwise known as syngas derived from any carbon source e.g. fossil fuels ( such 
as coal ,crude oil, shale oil/ oil shale, tar sands), biocrops/ biomass (plants and plant- derived substance waste), or other recyclable material (garbage, human and animal waste) or virtually any hydrocarbon feedstock, by reaction with steam or oxygen or by reforming of natural gas i.e. methane (Cui, 2014; Wikipedia-Synthetic Fuel). For instance, coal is converted into liquid fuel by ' combined gasification and liquefaction processes' while liquid fuel (oil) is extracted from oil shale by a process called 'retorting'. On the other hand, biomass is converted to ethanol (bio fuel) by 'fermentation' and to methane (biogas) by 'hydration'. Synthetic liquid fuels products outperform crude oil products, for instance table 1, shows the comparison of both products with the 2006 diesel requirement.

\begin{tabular}{|c|c|c|c|}
\hline Property & 2006 Diesel Requirement & Crude Oil Diesel & Synfuel Diesel \\
\hline Sulfur (ppm) & 15 & 500 & Zero \\
\hline Aromaics(\%) & -30 & -30 & Zero \\
\hline Cetane & -45 & -45 & $>74$ \\
\hline
\end{tabular}

Table 1: Comparison of Crude Oil And synthetic Liquid Fuels

Products Based on 2006 Diesel Requirement

\subsection{Study Objective}

Although the GTL process has been around for many years, it became economically viable because of the price of oil at more than $\$ 40$ per barrel (Brent), despite the fact that various report started that it is profitable in the $\$ 15$ to $\$ 25$ per barrel if the gas supply is nearly free or at least below $\$ 0.05 / \mathrm{MM}$ Btu (i.e. \$0.05/ M scf). Presently the international market price of natural gas is $\$ 2.77$ per MM Btu i.e. $\$ 2.77$ per M scf (Henry Hub; Oilprice.com), while in Nigeria the penalty for flaring stands at \$3.50/ M scf., since August 2011 (Ofoegbu, 2015). On the other hand, the price of crude oil is $\$ 78.10$ per barrel (Brent) while the world average prices for gasoline (petrol) and diesel is $\$ 1.13$ and $\$ 1.04$ per liter respectively (GlobalPetrolPrices.com). With a pump price of N145 (\$0.40) per litre, Nigeria has been ranked as the eighth cheapest place in the world to buy petrol (Femi Asu, punching.com).

From the forgoing, since there are 160 liters in a barrel, the price of a barrel of gasoline is (160 $\mathrm{x} \$ 1.13=\$ 180.8)$ while from the fact that GTL processes convert 10,000 scf of gas to one barrel of synthetic fuel, the cost of equivalent natural gas becomes $(\$ 2.77 \times 10=\$ 27.7)$. Therefore, even at a much higher gas price, the GTL venture will still be viable and would offer abundant clean fuels and feedstock for refiners, petrochemical companies, power generating companies that are facing stringent environmental requirements.

Also, of the various types of GTL conversion processes available, the FT-GTL process is presently the most used practical process, although conversion costs are very high due to expensive cryogenic oxygen production and the very huge cost of synthesis gas (hydrogen and carbon dioxide mixture) production, which is typically $60 \%$ of a plant cost. Figure 6 shows that the starting raw material for, both the indirect FT-GTL and the newly proposed direct GTL process by PEERI, is Natural gas and air. This investigation is aimed at developing a direct single step process for the conversion of methane to permanent liquid i.e. synthetic liquid fuels such as gasoline (petrol), kerosene and diesel at standard temperature and atmospheric pressure, for use by different types of vehicles, figures 7 .

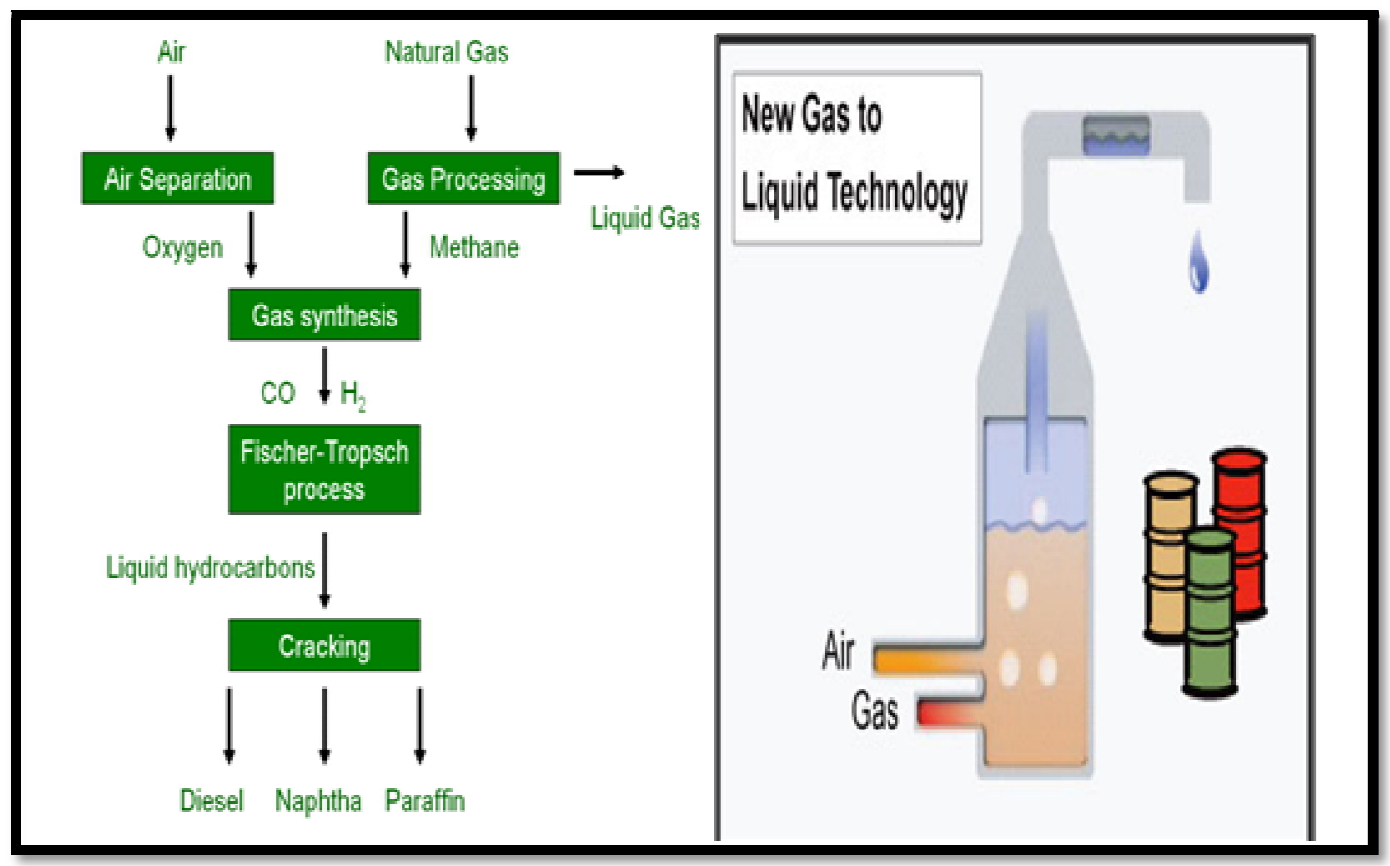

Figure 6: Compatibility of the Starting Raw Materials for the Indirect FT-GTL Process and the New Direct PEERI-GTL Process

Source: Adapted from Images of the GTL Processes 


\begin{tabular}{|c|c|c|c|c|c|}
\hline FUEL & PETROL & DIESEL & $\begin{array}{l}\text { NATURAL } \\
\text { GAS }\end{array}$ & $\mathrm{LPG}$ & $\begin{array}{l}\text { ELECTRI- } \\
\text { CITY }\end{array}$ \\
\hline $\begin{array}{l}\text { Chemical } \\
\text { Structure }\end{array}$ & $C_{4}$ to $C_{12}$ & $C_{8}$ to $C_{25}$ & $\begin{array}{l}\mathrm{CH}_{4}(83-99 \%), 2 \mathrm{H}_{6} \\
(1-13 \%)\end{array}$ & $\begin{array}{l}\mathrm{C}_{3} \mathrm{H}_{3} \text { (majority) } \\
\text { and } \mathrm{C} 4 \mathrm{H} 10\end{array}$ & $\mathrm{H}_{2}$ \\
\hline $\begin{array}{l}\text { Physical } \\
\text { State }\end{array}$ & Liquid & Liquid & Compressed Gas & Pressurized Liquid & Electricity \\
\hline $\begin{array}{l}\text { Reserve } \\
\text { Available }\end{array}$ & 40 years & 55 years & 60 years & 30 years & Unlimited \\
\hline Uses & $\begin{array}{l}\text { All types of } \\
\text { vehicles }\end{array}$ & $\begin{array}{l}\text { Heavy duty } \\
\text { vehicles }\end{array}$ & $\begin{array}{l}\text { All types of } \\
\text { vehicles. }\end{array}$ & Cars mainly & $\begin{array}{l}\text { Cars and } \\
\text { scooters }\end{array}$ \\
\hline $\begin{array}{l}\text { Pollution } \\
\text { level }\end{array}$ & Most polluting & $\begin{array}{l}\text { Cleaner than } \\
\text { Petrol }\end{array}$ & $\begin{array}{l}\text { Cleaner than } \\
\text { Petral, Diesel and } \\
\text { LPG }\end{array}$ & $\begin{array}{l}\text { Cleaner than } \\
\text { Petrol and Diesel }\end{array}$ & Least polluting \\
\hline Cost & Most expensive & $\begin{array}{l}\text { Cheaper than } \\
\text { Petrol }\end{array}$ & $\begin{array}{l}\text { Comparatively } \\
\text { cheapest }\end{array}$ & $\begin{array}{l}\text { Cheaper than } \\
\text { Petrol and Diesel }\end{array}$ & Cheopest \\
\hline $\begin{array}{l}\text { Energy } \\
\text { Content }\end{array}$ & $124.340 \mathrm{Btu} / \mathrm{gal}$ & 1 $37.380 \mathrm{Btu} / \mathrm{gal}$ & $\begin{array}{l}22453 \mathrm{Btu} / \mathrm{lb}-\mathrm{CNG} \\
84,820 \mathrm{Btu} / \mathrm{gal}= \\
\text { LNG }\end{array}$ & $91.410 \mathrm{Btu} / \mathrm{gal}$ & 3.414 Bfu/kWh \\
\hline
\end{tabular}

Figure 7: Uses and Some Other Properties of Some Liquid and Gaseous Fuels Source: Adapted From Images of the Uses and Properties of Liquid and Gaseous Fuels

\subsection{Study Significance}

Both gas liquefaction LNG and gas conversion to liquid GTL are viable processes to monetize isolated or stranded gas that serve different end markets. GTL products do not compete with LNG, rather they complement it. While for LNG, producers look for secured markets before embarking on the venture, the market for GTL products, as they are compatible with crude oil products, are infinite in size. Figure 8 shows that there is more market size (high demands) for liquid fuels (GTL) than for gaseous fuels (LNG), hence the necessity for Gas-To- Liquid Conversion.

\section{Market for GTL Liquids is Much Bigger Than the LNG Market}

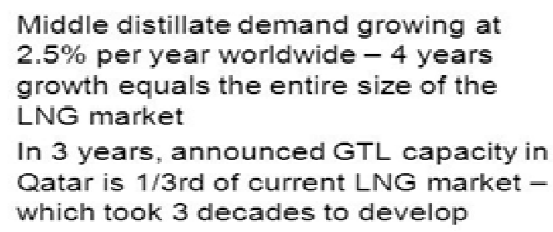

In 3 years, announced GTL capacity in Qatar is $1 / 3$ rd of current LING market which took 3 decades to develop

\section{Symtroleum}

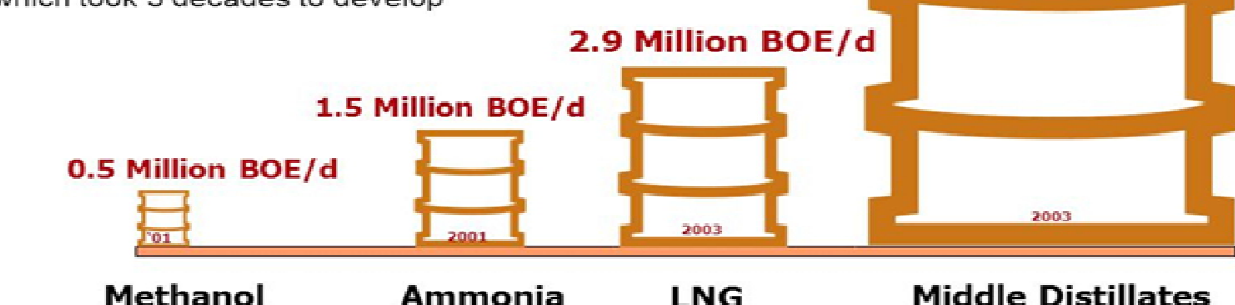

Sources: 2001- American Methanol Association, Fertecon Ltd., 2004 Bp statistical Review of World Energy

Figure 8: Market Demand Comparison for GTL and LNG

Source: Adapted From Images of the GTL Market

\section{Background}

There are precisely five practical ways of transporting natural gas (methane) to the consumer, figure 9:

- Flow it through a pipeline in the gaseous form

- Compress and transport it as compressed natural gas (CNG)

- Chill and transport it as liquefied natural gas (LNG).

- Chill, solidify and transport it as solid hydrates (NGH).

- Chemically convert natural gas into liquid (GTL) products that can easily be shipped to market, such as, methanol; ammonia; naphtha/ gasoline; diesel; kerosene etc. 


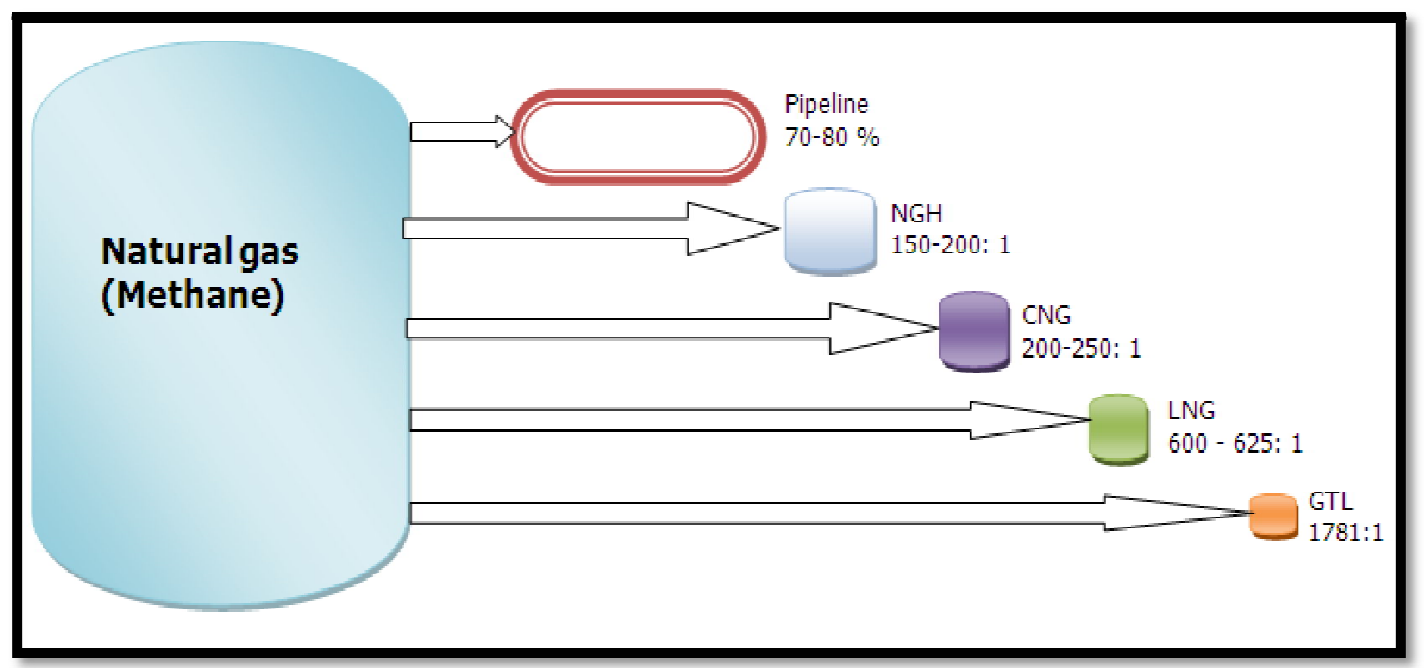

Figure 9: Illustrative Image Not to Scale

Much like the pipeline option, compressed natural gas (CNG), liquefied natural gas (LNG) and gas-to-solids (GTS)/ natural gas hydrate (NGH) options are the three other gas-to -gas (GTG) options to bring gas to market, which take advantage of the reduction in volume of the gas to economically transport the gas (Durr and Shah, 2007). That is, it is still gaseous methane compressed, chilled or solidified at $-162{ }^{\circ} \mathrm{C}(-259 \circ \mathrm{F})$, and it returns to gaseous phase if allowed to warm up to ambient condition.

On the other hand, the GTL process chemically converts methane molecules into other liquid compounds. Once converted, these liquids are stable and will remain in the liquid state

Generally, from the fact that, in existing GTL processes, every 10,000 cubic feet of natural gas (methane) is converted to 1.0 barrel (and $1 \mathrm{bbl}=5.615$ cubic feet of liquid), it follows that $\{10,000 \mathrm{cu} \mathrm{ft} / 5.615 \mathrm{cu} \mathrm{ft}=1780.94\}$ approximately 1781, figure 9, GTL volume reduction is (1781: 1). This implies that, about $1781 \mathrm{scf}$ of natural gas convert to 1 cubic feet liquid. Whatever the system, liquefaction or chemical conversion, it always involves control of pressure, temperature and the composition of the system in order to obtain the right kind of liquid (Perry, 1985).

\subsection{Relation of Liquids to Gases and Solids}

Each of the three homogeneous physical states (solid, liquid and gas) in which a substance can exist is called a phase or state (Heys, 1980). Although the liquid state is intermediate between the gaseous and solid states, it appears to be closer to the solid state than the gaseous state.

Figures 10 and 11 illustrates the relation of solid, liquid and gas by means of spheres in two dimensions.

The major characteristic feature of a solid is the orderly arrangement of its particles because the intermolecular attraction between the molecules is more dominant, and the movement of the molecules is restricted to vibration about a mean position. The same forces which hold molecules together in a solid (crystal) still hold them together in liquid, although less firmly. In a liquid intermolecular attraction is supreme, but the thermal energy of the molecules prevents them from occupying fixed positions. Thus, the structures formed in liquid are temporary i.e. constantly breaking down and reforming and in many cases the structures will be only partially complete. In contrast, a gas is characterized by the disorderly distribution of its particles since the distance between the molecules is greatly increased(Heys, 1980). In the solid, each sphere is in contact with six other spheres, while in the liquid, a given sphere may be in contact either six, five, or even four spheres as represented by the spheres numbered 1,2, and 3respectively.

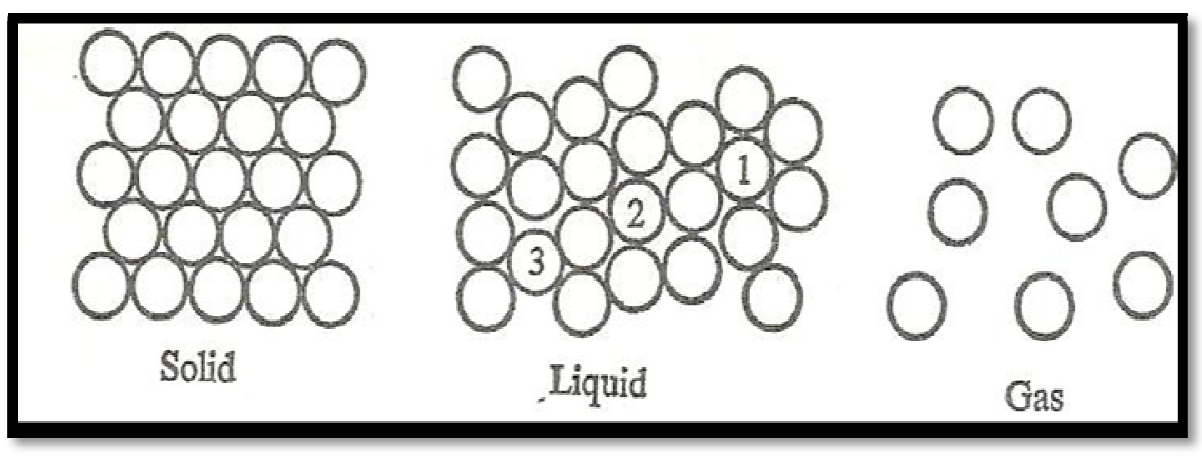

Figure 10: Relation of Solid, Liquid and Gas by Means of Spheres Source: Adapted from Heys, 1980 


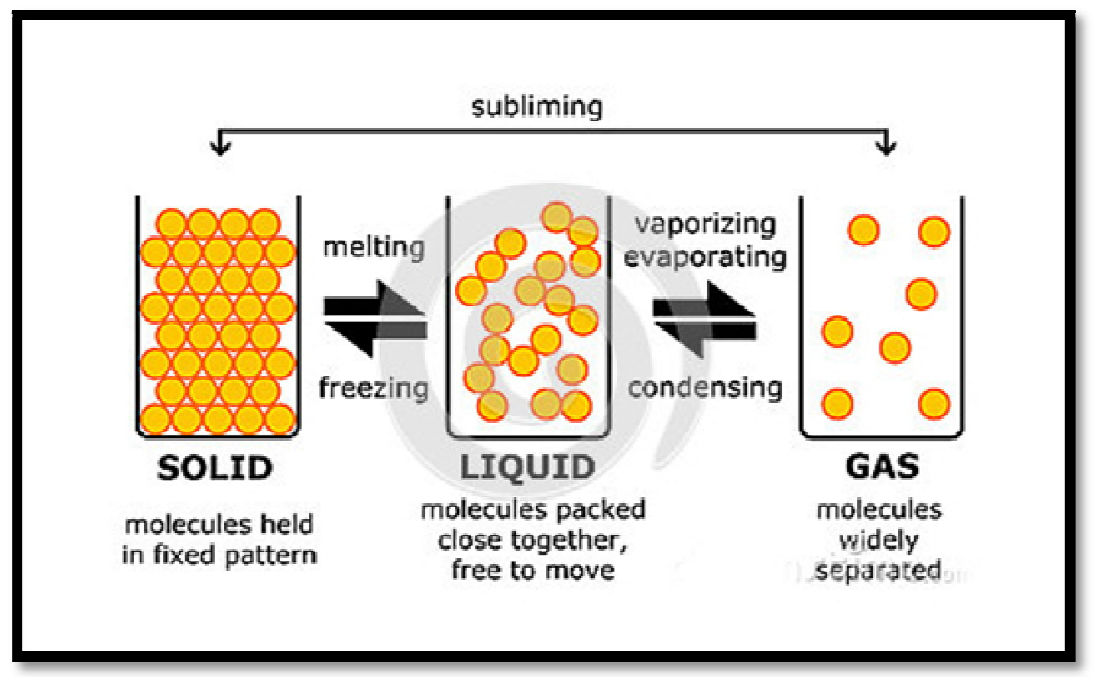

Figure 11: Relation of Solid, Liquid and Gas by Means of Spheres

Source: Adapted from the Images of Solid, Liquid and Gas

\subsection{Gas Liquefaction Concept}

The fundamental gas laws by Robert Boyle (1627-1691), Jacques a. Charles (1746-1823), Joseph L. Gay-Lussac (1778-1850) and Amadeo Avogadro (1776-1856) started with observed temperature and pressure relation with air experiments (Ebbing, et al., 1995; Ikoku, 1980). There finding was used on a hypothetical fluid known as an ideal gas to develop the equation of state for an ideal gas $(p V=n R T)$, where $p$ is absolute pressure in psia, $V$ is volume in cubic feet, $T$ is absolute temperature in ${ }^{\circ} \mathrm{R}, \mathrm{n}$ is number of $\mathrm{lb}$-moles and $\mathrm{R}$ is the universal gas constant (10.732 psia ft $\left.3 / \mathrm{lb}-\mathrm{mole} \cdot \mathrm{R}\right)$. The ideal gas describes the behavior of most real/ actual gases at temperature and pressure conditions close to atmospheric (14.7 psia), (Ikoku, 1980). At moderate pressures real gas tends to compress more than the ideal gas law indicates (supercompressible), particularly for temperatures close to the critical temperature. At high pressure the gas tends to compress less than the ideal gas law predicts. To correct for the deviation between the measured or observed volume and that calculated using the ideal gas law, an empirical factor Z, called the gas deviation factor or the Z-factor, is used. Z is the ratio of the actual volume of $n$ moles of gas and the ideal (calculated) volume of $n$ moles of gas at the same Pressure and Temperature. The real gas equation of state becomes $(\mathrm{pV}=\mathrm{ZnRT})$. $\mathrm{Z}$ is dimensionless and is approximately one $(\mathrm{Z} \approx 1)$ at atmospheric pressure. Subsequent investigations, between 1961 to 1963, by Thomas Andrews, on liquefaction of real gases such as carbon dioxide, oxygen, nitrogen, helium and hydrogen, revealed that at room temperature they cannot be liquefied by application of pressure alone, rather it requires the combined effect of first cooling (down to or below a particular temperature 'critical temperature') and then, the application of pressure (Nagpal, 2017). Each gas has a critical temperature (table 2) above which it cannot be liquefied however high pressure may be applied on it.

\begin{tabular}{|c|c|c|c|c|c|}
\hline & $\begin{array}{c}\text { Boiling point at } \\
14.696 \text { psia } \\
\text { oF }\end{array}$ & $\begin{array}{c}\text { Freezing point } \\
\text { at } 14.696 \text { psia } \\
\text { oF }\end{array}$ & $\begin{array}{c}\text { Critical } \\
\text { temperature }{ }^{\circ} \mathrm{F}\end{array}$ & $\begin{array}{l}\text { Critical pressure } \\
\text { psia and (Critical. } \\
\text { vol. cu ft lb) }\end{array}$ & $\begin{array}{l}\text { State at } \\
68^{\circ} \mathrm{F} \\
\left(20^{\circ} \mathrm{C}\right)\end{array}$ \\
\hline Methane $\mathrm{C}_{1}$ & -259 & -296.45 & -116.68 & $667.8 \&(0.0991)$ & Gas \\
\hline Ethane $\mathrm{C}_{2}$ & -128 & -297.04 & 90.10 & $707.8 \&(0.0788)$ & Gas \\
\hline Propane $\mathrm{C}_{3}$ & -44 & -305.82 & 206.01 & $616.3 \&(0.0737)$ & Gas \\
\hline Isobutane $\mathrm{C}_{4}$ & +11 & -255.28 & 274.96 & $529.1 \&(0.0702)$ & Gas \\
\hline n-butane $\mathrm{C}_{4}$ & 31 & -217.05 & 305.62 & $550.7 \&(0.0724)$ & Gas \\
\hline Isopentane $\mathrm{C}_{5}$ & 82.11 & -255.82 & 369.03 & $490.4 \&(0.0675)$ & Liquid \\
\hline n-pentane $\mathrm{C}_{5}$ & 96.91 & -201.51 & 385.6 & $488.6 \&(0.0679)$ & Liquid \\
\hline Hexanes $\mathrm{C}_{6}$ & 145 & -139.58 & 453.6 & $436.9 \&(0.0688)$ & Liquid \\
\hline Heptanes $\quad \mathrm{C}_{7}$ & 195 & -131.05 & 512.7 & $396.8 \&(0.0691)$ & Liquid \\
\hline Octanes $\mathrm{C}_{8}$ & 245 & -70.17 & 564.10 & $360.6 \&(0.0690)$ & Liquid \\
\hline Nonanes $\mathrm{C}_{9}$ & 303.48 & -64.28 & 610.54 & $331.8 \&(0.0684)$ & Liquid \\
\hline Decanes $\mathrm{C}_{10}$ & 345 & -21.35 & 615.6 & $304.4 \&(0.0679)$ & Liquid \\
\hline Oxygen $\mathrm{O}_{2}$ & -297.4 & -361.8 & $-181.1(-118 \circ \mathrm{C})$ & $736.9 \&(0.0382)$ & Gas \\
\hline Nitrogen $\mathrm{N}_{2}$ & -320.4 & -346.0 & $-232.4(-147 \circ \mathrm{O})$ & $493.0 \&(0.0514)$ & Gas \\
\hline
\end{tabular}

Table 2: Physical Constants of Paraffin Hydrocarbons (Natural Gas)

Source: Adapted from Ikoku, 1980

The liquefaction of gas takes place when the intermolecular forces of attraction become so high that they bind the gas molecules together to form the liquid state (Nagpal, 2017). The intermolecular forces of attraction can be increased either by increasing the pressure so that the molecules come close together or by cooling the gas so that the kinetic energy 
of the molecules decreases and they become slower. The two categories of methane gas liquefaction processes are the transitional and permanent gas liquefaction processes:

Transitional gas liquefaction processes in which, under specified temperature and pressure, the volume of the gas is drastically reduced for transportation convenience. In this case, the liquefied gas reverts to gaseous state at the point of use. The methods for liquefying gas with this approach are:

- Compression and external cooling (Heys, 1980), in which compression of the gas causes evolution of heat due to work done on the gas, and this heat of compression is removed by external cooling. Precisely, the gas is compressed by a pump and passed into the condenser coils, which are fitted with cooling fins. As heat is lost to the air, the gas condenses to liquid. An example is the stage mechanical refrigeration where heat is transferred through refrigerants to a high level heat sink 'cascade cycle' (Ikoku,1980), figure 12.

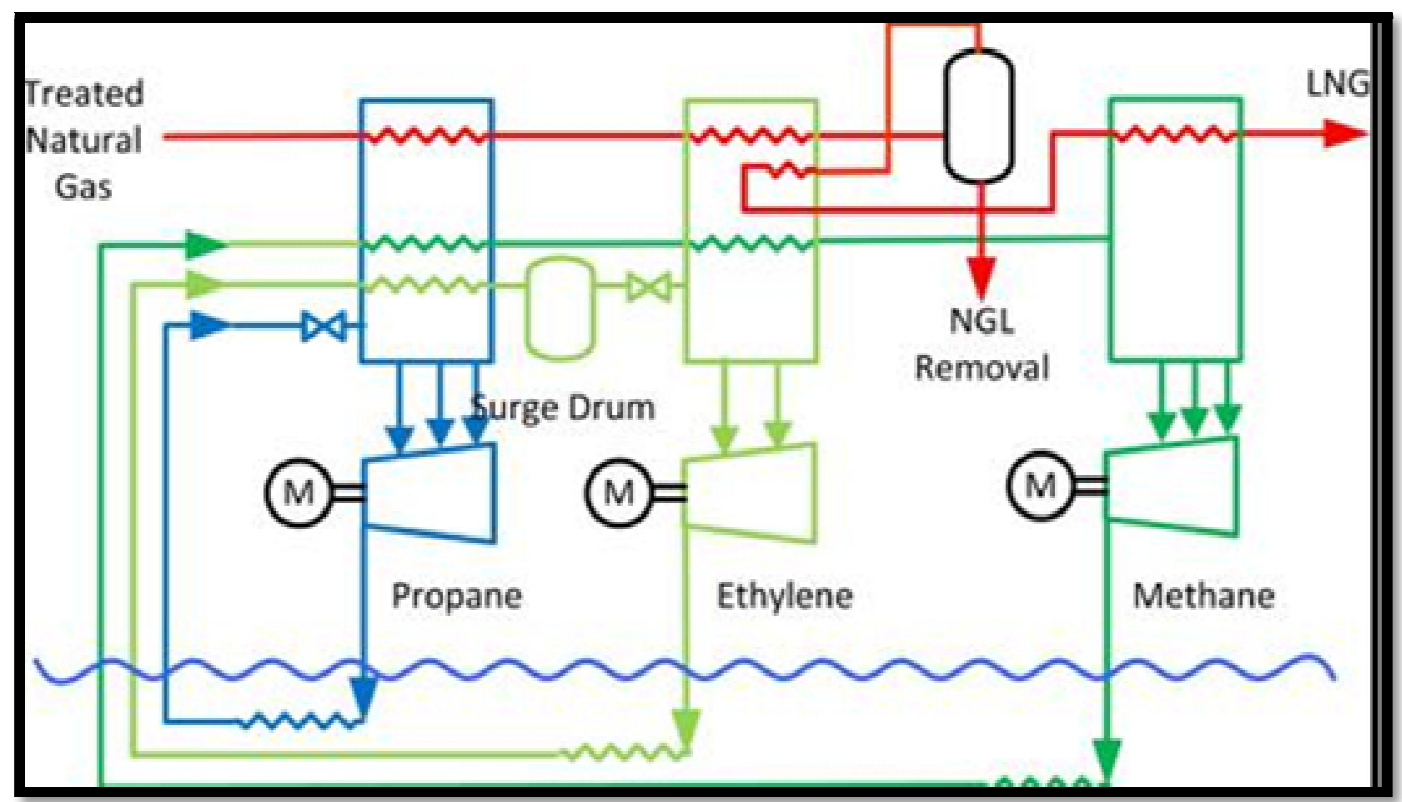

Figure 12: Schematic of the Cascade Cycle Liquefaction Process

Source: Adapted from the Images of Cascade Liquefaction

- Cooling by performance of external work (Heys, 1980), which involves compression, cooling and subsequent adiabatic expansion (in which heat is neither gained nor lost externally). The cooling effect of the expansion reduces the temperature below the critical temperature, and the gas liquefies. An example is the use of expander cycle i.e. the turbo-expander cycle, figure 13.

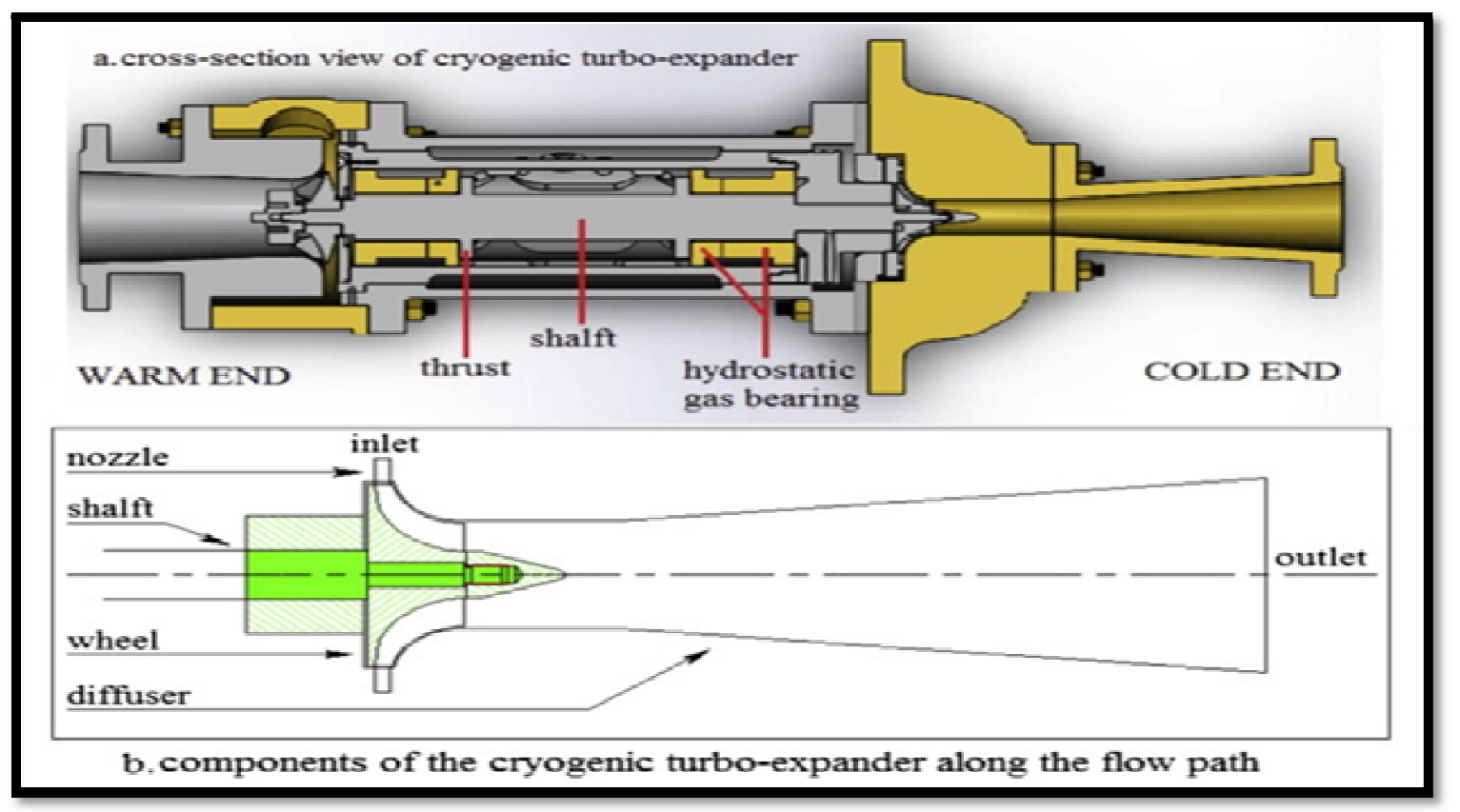

Figure 13: The Turbo Expander Process

Source: Adapted from the Images of the Turbo Expander 
- Joule-thomson effect (Heys, 1980), which involves compression, cooling and subsequent expansion by passing it through a fine aperture (joule-thomson expansion valve) for further cooling. The gas reaching the valve is so cold, that when it expands through the valve, liquefaction occurs. Precisely, it is an irreversible expansion of a gas from a high pressure to a lower pressure through a well-insulated valve 'joule-thomson cycle' (Ikoku, 1980), figure 14.

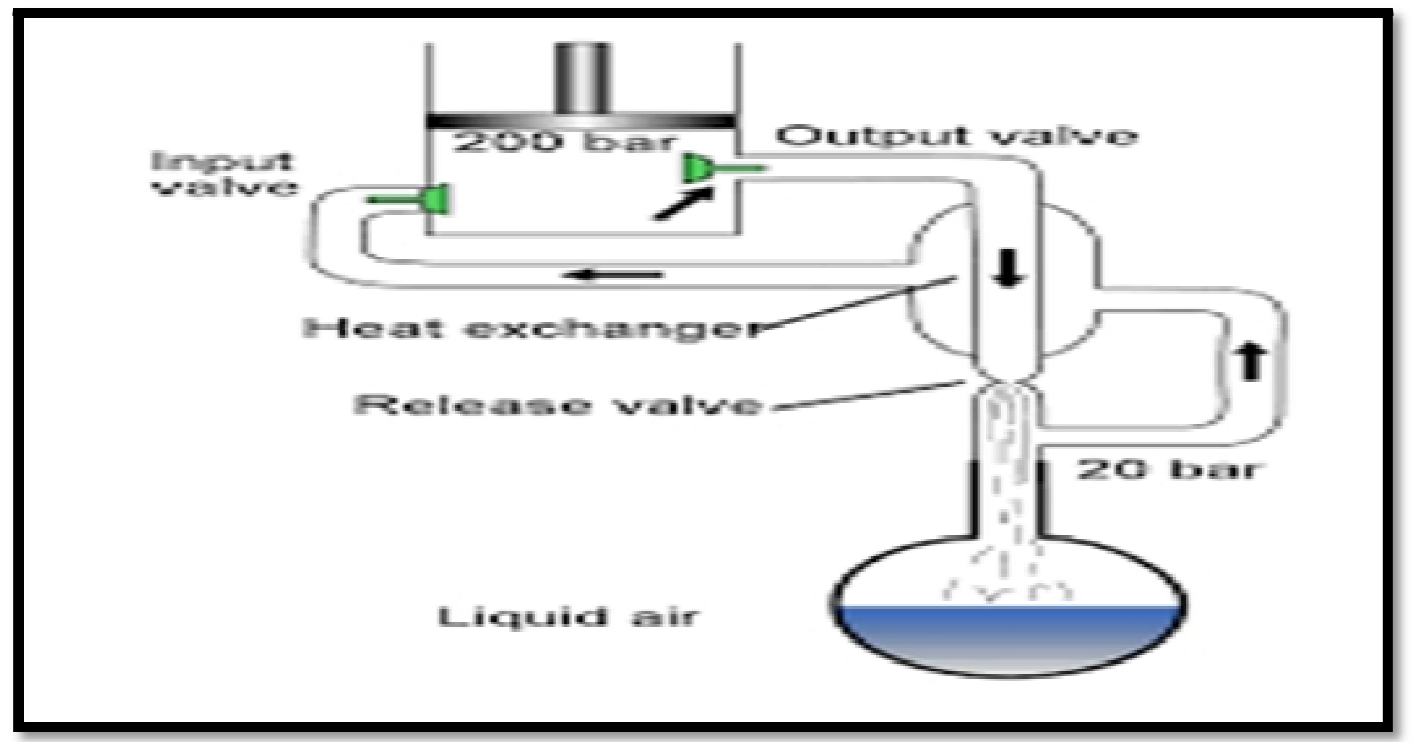

Figure 14: Application of Joule-Thomson Using the Air Source: Adapted from Images of Joule-Thomson Valve

Permanent gas liquefaction processes in which chemical transformation of the gas molecules occur simultaneously with super drastic volume reduction, such as the gas-to-liquid (GTL) i.e. to Clean synthetic Fuels (e.g. gasoline, diesel, kerosene etc.) and Green Chemicals \{e.g. methanol, ammonia, dimethylether (DME), etc. from Gas.

\subsection{Gas to Liquid Concept}

Gas - to - Liquid (GTL) is a chemical conversion route for converting methane (natural gas) to liquid fuel products, which involves the rearrangement of molecules (Shad and Durr, 2007). The liquid products are either liquid hydrocarbons (gasoline, naphtha, kerosene, diesel etc.) or chemical liquids \{methanol, ammonia, refinery hydrogen, dimethylether (DME), ethanol and other alcohols\}. The two distinct GTL production routes are, indirect processes and direct processes.

\subsubsection{Indirect Processes}

In the indirect process, natural gas (methane) is either, catalytically or non-catalytically converted to synthesis gas 'syngas' ( a mixture of carbon monoxide ' $\mathrm{CO}$ ' and hydrogen ' $\mathrm{H}_{2}$ ') and subsequently, with the help of selectivity catalyst, which is targeted at the production of any or some specific products in high market demand, the syngas is converted to any of liquid products in figure 15, through various routes such as oxygenate-based (to produce methanol, DME); FischerTropsch (FT)-based (to produce diesel, naphtha, kerosene, lubes etc.) and other chemicals ( ammonia).

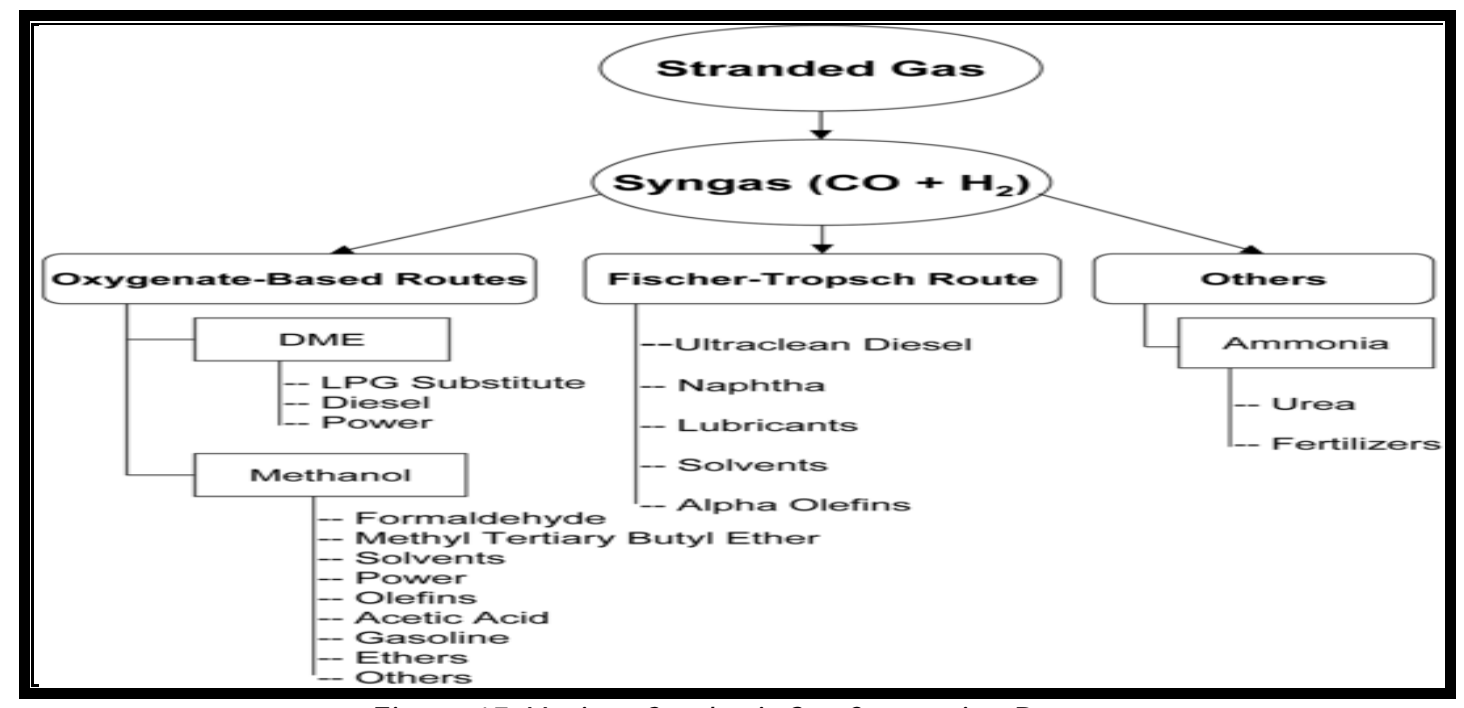

Figure 15: Various Synthesis Gas Conversion Routes

Source: Adapted from Shad and Durr, 2007 


\subsubsection{Direct Processes}

The low reactivity of methane makes it difficult to directly convert it to liquid. However, there are some direct GTL mechanisms in use with very low desired products yields such as (i) cold flame oxidation for methanol and formaldehyde production (ii) direct oxidation for $\mathrm{C}_{2}+$ hydrocarbons production (iii) oxychlorination for the production of methyl chloride and subsequently, production of aliphatic and aromatic hydrocarbons (iv) indirect oxidation for ethylene production and (v) catalytic pyrolysis for ethylene production (Shad and Durr, 2007). The most recent proposed direct GTL routes are (vi) chemical oxidative coupling of methane/ methane electrochemical oxidative coupling (Silva and Miranda, 2016) and (vii) the single-step, low temperature process is being developed by (PEERI).

\section{General Reaction Mechanism of the GTL Processes}

The overall reaction mechanism of the GTL processes is based on the formation of radicals and radicals' polymerization or hybridization using highly selectivity catalyst, targeted at specific end products.

\subsection{Mechanism of Catalytic Reactions}

A catalyst is defined as a substance which alters the rate of a reaction, but remains unchanged in quantity at the end of the reaction or at equilibrium (Heys, 1980). The ability of a catalyst to increase or accelerate the rate of a chemical reaction is known as the activity of the catalyst, and the degree of acceleration can be as high as $10^{10}$ times in certain reactions (byjus.com). We distinguish between the following categories of catalysts (i) Acid catalysts e.g. concentrated sulfuric acid $\mathrm{H}_{2} \mathrm{SO}_{4}$ (ii) Base catalysts such as hydroxide or alkoxide (iii) Transition metal catalyst, most commonly palladium, platinum or nickel (iv) Organometallic reagents and catalysts e.g. organo-magnesium, organo-lithium, organocopper, organo-palladium useful for preparation of new carbon-carbon bonds (v) Rare earth compounds(Ce, La)/ rare earth oxides (vi) Phase-transfer catalyst ( substances that transfer ion from an aqueous phase to an organic phase and vice versa, et cetera (Brown et al., 2005) . Catalyst actions are homogeneous when the catalyst and the reacting substances are in the same physical state (e.g. reactions involving gaseous or liquid in the presence of acid or base catalyst), and heterogeneous when they are in different physical states (e.g. gaseous or liquid reactants with a transition metals catalyst). Transition metals create catalytic surface which temporarily adsorb certain components of the reactants on its surface as it flows through it. The bond formed during this reactants adsorption on the catalytic surface must be strong enough to make the catalyst active, but not so strong to make the reactant molecules immobilized on the catalytic surface, thereby leaving no further space for new reactants to get adsorbed. This is referred to as chemisorption. Catalysts are highly specific compounds that are highly selective in nature. Selectivity of catalyst (selectivity catalyst) have the ability to direct the reaction to yield particular products (excluding others), and it can be controlled in several ways, such as, by structural, chemical, electronic, compositional, kinetic and energy consideration. Table 3 shows some Catalysts and their application. For instance, the transition metals used in hydrogenation are able to adsorb large quantities of hydrogen onto their surfaces, probably by forming metal-hydrogen sigma bonds, as well as adsorb alkenes on the metal surfaces with formation of carbon-metal bonds. Subsequently, under some experimental conditions, hydrogen atoms are added to the alkene to form alkane, figure 16.

\begin{tabular}{|c|c|c|}
\hline Catalyst & Function & Example \\
\hline Metals & Hydrogenation & $\mathrm{Fe}, \mathrm{Ni}, \mathrm{Pt}, \mathrm{Ag}$ \\
& Dehydrogenation & \\
\hline Semiconducting Oxides and Sulphides & Oxidation & $\mathrm{NiO}, \mathrm{ZnO}, \mathrm{MgO}$, \\
& Dehydrogenation & $\mathrm{Bi}_{2} / \mathrm{MoO}_{3}$ \\
& Desulphurization & \\
\hline Insulating Oxides & Dehydration & $\mathrm{Al}_{2} \mathrm{O}_{3}, \mathrm{SiO}_{2}, \mathrm{MgO}$ \\
\hline Acids & Polymerization & $\mathrm{H}_{3} \mathrm{PO}_{4}, \mathrm{H}_{2} \mathrm{SO}_{4}$, \\
& Isomerization & $\mathrm{SiO}_{2} / \mathrm{Al}_{2} \mathrm{O}_{3}$ \\
& Cracking & \\
\hline & Alkylation & \\
\hline
\end{tabular}

Table 3: Catalysts and Their Application

Source: Adapted from Atkins, 1979 


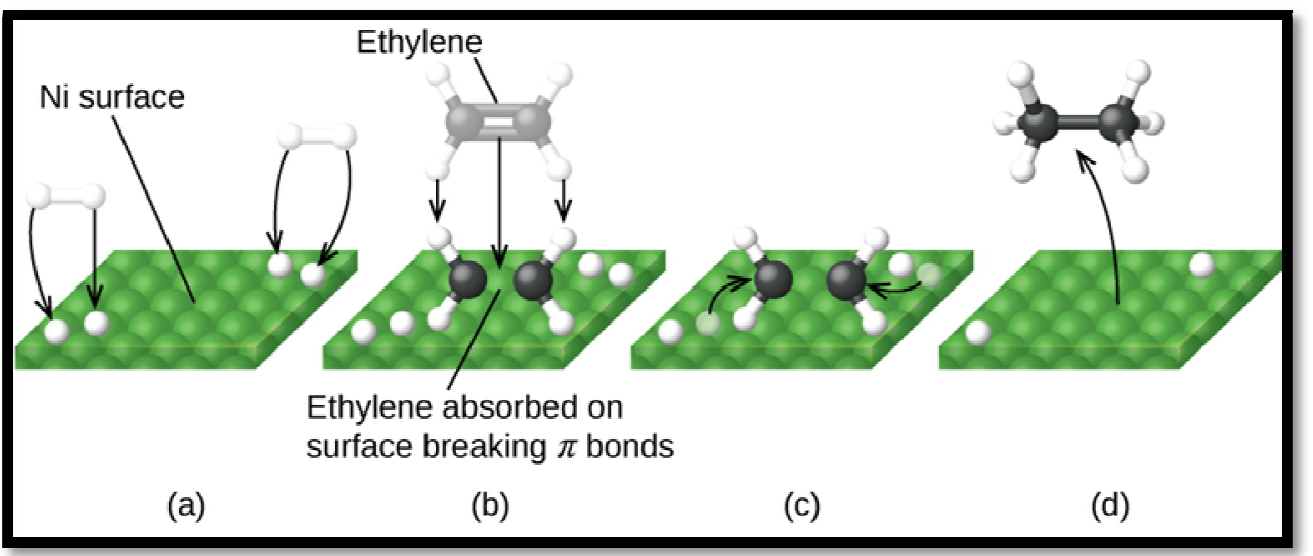

Figure 16: There are four Steps in the Catalysis of the Reaction $\mathrm{C}_{2} \mathrm{H}_{4}+\mathrm{H}_{2}$ 回 $\mathrm{C}_{2} \mathrm{H}_{6}$ by

Nickel (A) Hydrogen is Adsorbed on the Surface, Breaking the H-H Bonds and Forming Ni-H Bonds

(B) Ethylene Is Adsorbed on the Surface, Breaking the $\Pi$-Bond and Forming Ni-CBonds

(C) Atoms Diffuse across the Surface and form new C-H Bonds When They Collide

(D) $\mathrm{C}_{2} \mathrm{H}_{6}$ Molecules Escape from the Nickel Surface, since they are not strongly attracted to Nickel

Source: Adapted from Images of Transition Metal Catalytic Surface

\subsection{Formation of Radicals}

Radicals are produced from a molecule by cleavage of a bond in such a way that each atom or fragment participating in the bond retains one electron (Brown et al., 2005), a process referred to as homolytic bond cleavage as in the reaction

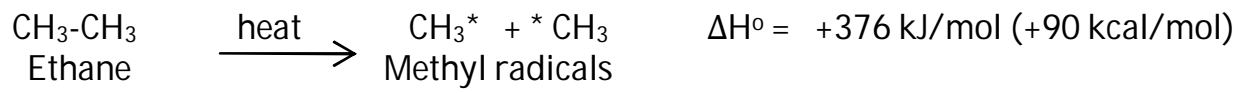

This is unlike the much common heterolytic bond cleavage in which a bond breaks and one of the species retains both electrons. The common radicals generated from methane are, methyl radicals $\left(\mathrm{CH}_{3}{ }^{*}\right)$, methylene radicals $\left({ }^{*} \mathrm{CH}_{2}{ }^{*}\right)$, hydrogen radicals $\left(\mathrm{H}^{*}\right)$. Because radicals are electron-deficient, they are highly reactive and behave as electrophiles. The radical chain mechanism involves three steps (i) chain initiation (ii) chain propagation and (iii) chain termination(Brown et al., 2005).

Chain Initiation involves the formation of radicals from non-radical compounds by either thermal (cleavage by heating i.e. thermolysis); photolysis (cleavage by light i.e. light-induced homolysis); catalyst singly or in combinations.

Chain propagation involves the reaction of a radical and a molecule to give a new radical. This can be repeated thousands of times as long as neither radical is removed by a different reaction. Thus, after the radical chain is initiated (i.e. heat or light energy is supplied to cause bond cleavage and generation of radicals), the heat of reaction (in the propagation step) is derived entirely from the heat of reaction of the individual chain propagation step, which could be either exothermic (reactions that release energy to the surrounding) or endothermic (reactions that absorb energy to the surrounding), (Sherman and Sherman, 1999). Most often, energy is required to break the bond to form radicals while energy is released when radicals form bond. The sum of the heats of reaction for each propagation step is equal to the observed heat of reaction.

Chain termination involves destruction of radicals by either

- Radical couplings (combination) to form a new covalent bond i.e.

$\mathrm{CH}_{3} \mathrm{CH}_{2}{ }^{*}+{ }^{*} \mathrm{CH}_{2} \mathrm{CH}_{3} \longrightarrow \mathrm{CH}_{3} \mathrm{CH}_{2}-\mathrm{CH}_{2} \mathrm{CH}_{3}$

Or

- Disproportionate which involves the transfer of a hydrogen atom from the beta position of one radical to another radical and formation of an alkane and an alkene formed by the merging of the single bond of the transferred with single bond of the other radical.

$\mathrm{CH}_{3} \mathrm{CH}_{2} *+\mathrm{CH}_{3}-\mathrm{CH}_{2} * \longrightarrow \mathrm{CH}_{3} \mathrm{CH}_{3}+\mathrm{CH}_{2}=\mathrm{CH}_{2}$

\subsection{Reaction Mechanism of the Indirect Fischer-Tropsch - GTL Processes}

In general, Fischer-Tropsch (FT) technology is the process of chemically converting natural gas into liquids (GTL), coal to liquids (CTL), biomass to liquids (BTL) or bitumen from oil sands to liquids (OTL). All four processes, usually known as Gas-to-Liquids(Kurevija et al., 2007). It consists of three technological separate sections (a) in the first step carbon feedstock is reacted with oxygen and steam inside of gasifier/ reformer to generate a mixture of hydrogen and carbon monoxide $\left(\mathrm{H}_{2}+\mathrm{CO}\right)$ called syngas, which can be used in many processes like fertilizer, methanol and specialty chemical production. In addition, this step generates waste heat which could produce steam-derived electricity in IGCC power plants as side-product of the GTL process, thereby increasing the overall energy efficiency and helping to offset the large cost of the equipment. (b) in the second step, the syngas inside F-T synthesis reactor in the presence of a catalyst at high pressure undergoes reformation, to long chain carbon hydrogen molecules, named F-T wax or paraffin. (c) in the 
third step these long chain molecules are split into shorter-length hydrocarbon molecules (diesel, naphtha, kerosene, LPG) in hydrocracking stages that are similar to crude oil refining.

The FT-GTL process as applied to natural gas, starts with gas treatment plant for removal of sulfur, carbon dioxide, water, heavier hydrocarbon components, and other contaminants, and reformation of purified natural gas (methane) to synthesis gas or syngas by breaking its molecules into a mixture of two diatomic molecules, hydrogen and carbon monoxide $\left(\mathrm{H}_{2}\right.$ and $\left.\mathrm{CO}\right)$, with a ratio of $2: 1$, that provide the building blocks upon which an entire field of fuel science and technology is based. Unlike methane, syngas is very reactive and can be converted by a wide range of processes (reforming process) into a variety of useful chemicals and materials. In the FT process, the syngas is converted to hydrocarbons building blocks $\left(-\mathrm{CH}_{2}-\right)$ or hydrocarbons chain extension in presence of a catalyst which can produce different compounds of hydrocarbons (liquids) via polymerization of the hydrocarbon building block, figure 17. Essentially, the FT-GTL synthesis is a bond forming exothermic reaction in which about $20 \%$ of the chemical energy is released as heat. Temperature, pressure and catalyst determine the direction of the three chain growth reactions occurring at the same time with syngas.

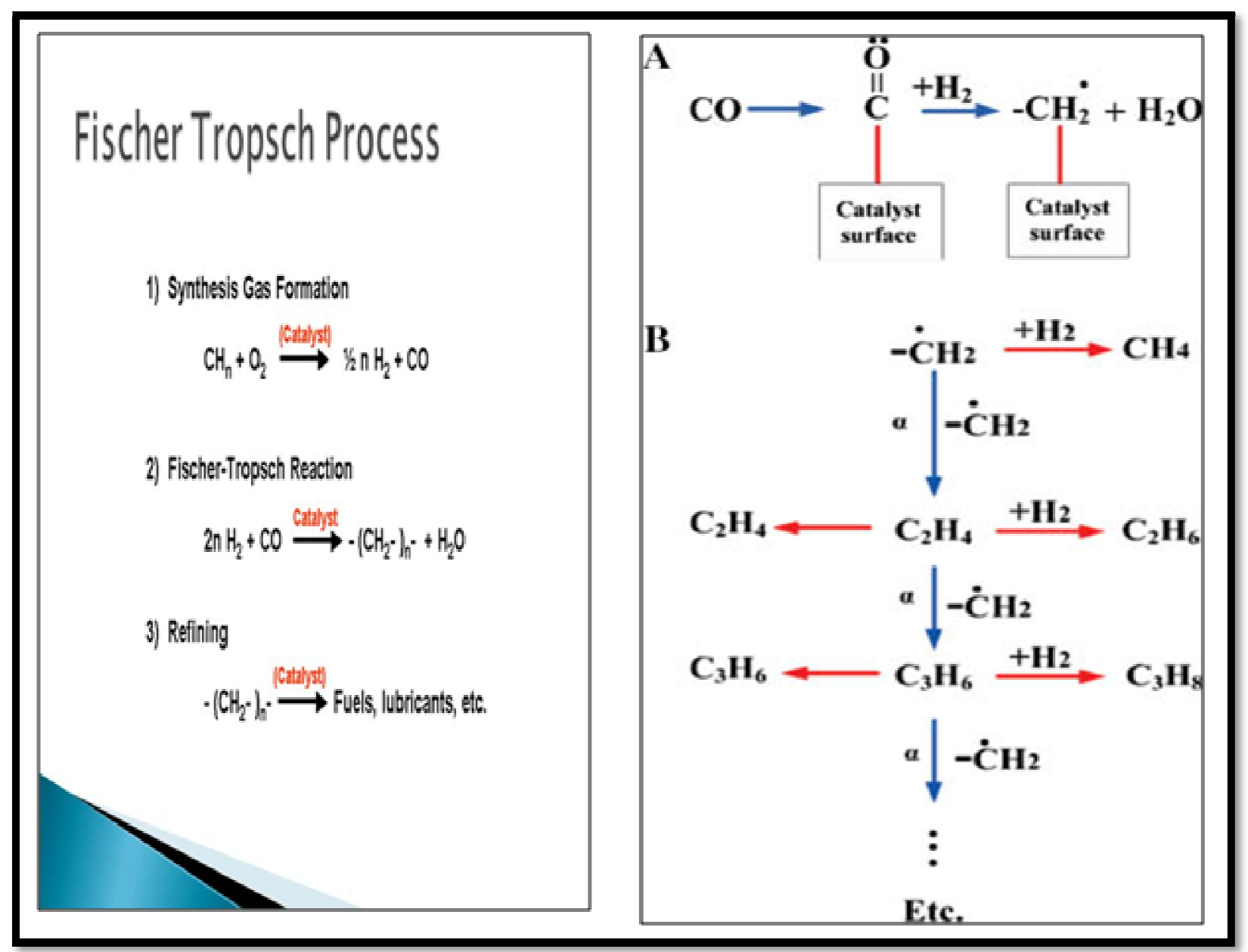

Figure 17: Synthesis Gas Formation and Subsequent Conversion to Alkanes Process Source: Adapted from Images of Syngas to Alkanes

The first product direction involves dissociation (splitting) carbon monoxide CO into C and O, after which C- atoms hydrogenate to $\mathrm{CHx}$ species and subsequently couple to longer hydrocarbon as follows:

$\begin{array}{lll}\mathrm{C}+\mathrm{H} & \longleftrightarrow \mathrm{CH} \\ \mathrm{CH}+\mathrm{H} & \longleftrightarrow \mathrm{CH}_{2} \\ \mathrm{CH}_{2}+\mathrm{H} & \longleftrightarrow & \mathrm{CH}_{3} \\ \mathrm{O}+\mathrm{H} & \longleftrightarrow & \mathrm{OH} \\ \mathrm{OH}+\mathrm{H}_{2} & \longleftrightarrow & \mathrm{H}_{2} \mathrm{O} \\ \mathrm{H}_{2} \mathrm{O}+\mathrm{CO} & \longleftrightarrow \mathrm{H}_{2}+\mathrm{CO}_{2} \\ \mathrm{CO} & \longleftrightarrow & \mathrm{CO}_{2}+\mathrm{C}\end{array}$

This is responsible for the deposition of carbon in the reactor tubes.

In subsequent reaction, referred to as catalytic hydrogenation, hydrogen molecules split apart and add across the double bonds of unsaturated alkene hydrocarbons, converting it to fully saturated alkane hydrocarbons (in the presence catalyst such as nickel, palladium or platinum).

$\mathrm{CH}_{2}=\mathrm{CH}_{2}+\mathrm{H}_{2} \stackrel{\mathrm{Ni} \text {, Catalyst }}{\longrightarrow} \mathrm{CH}_{3} \mathrm{CH}_{3}$ 
$\mathrm{CH}_{3} \mathrm{CH}=\mathrm{CH}_{2}+\mathrm{H}_{2} \stackrel{\mathrm{Ni} \text {, Catalyst }}{\longrightarrow} \mathrm{CH}_{3} \mathrm{CH}_{2} \mathrm{CH}_{3}$

The unsaturated alkene hydrocarbons molecules usually add to themselves at normal condition, under the influence of certain catalysts (e.g. concentrated sulphuric acid), to form very long chain molecules in a process referred to as polymerization. By varying the polymerization conditions, the amount of chain branching and the length of the chain can be varied, hence the desired product. $\quad \mathrm{nCH}_{2}=\mathrm{CH}_{2}\left[\mathrm{CH}_{2}=\mathrm{CH}_{2}\right] \mathrm{n}$

For example: the process can be used to react, butenes (olefin molecules with four carbon atoms) with iso-butane (branched paraffin molecules, or isoparaffins with four carbon atoms) to obtain a high octane (with eight carbon atoms) olefinic petrol blending component called polymer gasoline.

The overall reactions which, hides the mechanistic complexity can be described by chemical equations of the form.

Formation of alkanes (paraffins)

$\mathrm{nCO}+(2 \mathrm{n}+1) \mathrm{H}_{2} \longrightarrow \mathrm{C}_{\mathrm{n}} \mathrm{H}_{2 \mathrm{n}+2}+\mathrm{nH}_{2} \mathrm{O}$ +heat.

Formation of alkenes (Olefins)

$\mathrm{nCO}+2 \mathrm{nH}_{2} \longrightarrow \mathrm{C}_{\mathrm{n}} \mathrm{H}_{2 \mathrm{n}}+\mathrm{nH}_{2} \mathrm{O}$ +heat

Formation of oxygenates: alcohols or other oxygen containing compounds

$\mathrm{nCO}+2 \mathrm{nH}_{2} \mathrm{C}_{\mathrm{n}} \mathrm{H}_{2 \mathrm{n}+1} \longrightarrow \mathrm{OH}+(\mathrm{n}-1)\left(\mathrm{H}_{2} \mathrm{O}\right)$ theat

The high molecular weight hydrocarbons produced in the above reactions are synthesized by chain-growth process to final upgraded end products, with chain length determined by catalyst selectivity and reaction conditions i.e. temperature, pressure and residence time.

This upgrading process is used to improve liquid fuel selectivity and quality of the specific products. It involves converting the heavier F T syncrude products (paraffins, olefins and oxygenates), to a range of final products comprising light hydrocarbons $\left(\mathrm{C}_{1}\right.$ and $\left.\mathrm{C}_{2}\right)$, LPG $\left(\mathrm{C}_{3}\right.$ and $\left.\mathrm{C}_{4}\right)$, ultra- clean naphtha/ gasoline $\left(\mathrm{C}_{5}-\mathrm{C}_{11}\right)$, ultra-clean kerosene/ diesel $\left(\mathrm{C}_{12}-\right.$ $\mathrm{C}_{20}$ ) and wax $\left(>\mathrm{C}_{20}\right)$ fractions, high quality lubes and white oils, linear alpha olefins using conventional refinery processes such as distillate hydocracking, catalytic reforming, Oligomerization of the $\mathrm{C}_{3}$ to $\mathrm{C}_{6}$ olefins, hydrocracking of the waxes, hydrogenation, isomerization and fractionation with $98 \%$ efficiency. Other possible end products include methanol, dimethylether (DME), alcohols, with water and carbon dioxide produced as by-product. The high alcohol $\mathrm{C}_{1}-\mathrm{C}_{10}$ can act as additive to gasoline while as an alternative to fuels, the waxy portion could be converted to lubricant, drilling fluids waxes and other high value specialty products.

Usually, in practice, some plants are aimed at producing gasoline (petrol) while others aim at maximizing the yield of middle distillates, notably kerosene and diesel (gas oil), depending on market demand, table 4. We distinguish between two major commercial FT processes:

- Low temperature F-T (LTFT), which operates at around 220-270 ${ }^{\circ} \mathrm{C}\left(428-518{ }^{\circ} \mathrm{F}\right.$ ) and 20 bars (290 psi), using either tubular or slurry bed reactor to produce large fraction heavy waxy hydrocarbons which can be converted into high quality middle distillates of clean diesel, kerosene and naphtha.

- High temperature F-T (HTFT), which operates at around 300-350 ${ }^{\circ} \mathrm{C}\left(572-662{ }^{\circ} \mathrm{F}\right)$ and 20 bars (290 psi), using fluidized bed reactor to produce light syncrude and olefins which can be converted into high quality middle distillates diesel and some lower distillate petrol (motor gasoline) fuels.

\begin{tabular}{|c|c|c|}
\hline Fraction & \% Weight & End Market \\
\hline $\mathrm{C}_{1}-\mathrm{C}_{4}$ & $5-10$ & Fuels \&Petrochemicals Feedstock \\
\hline $\mathrm{C}_{5}-\mathrm{C}_{9}$ (gasoline/ naphtha) & $15-20$ & $\begin{array}{c}\text { Olefin plant feedstock or catalytic reforming unit to } \\
\text { produce gasoline and/ or aromatics feedstock }\end{array}$ \\
\hline $\mathrm{C}_{10}-\mathrm{C}_{16}$ (kerosene) & $20-30$ & Jet fuel \& paraffins \\
\hline $\mathrm{C}_{11}-\mathrm{C}_{22}$ (diesel) & $10-15$ & Diesel fuels \\
\hline $\mathrm{C}_{23}+$ & $30-45$ & Waxes and synthetic lubricants \\
\hline
\end{tabular}

Table 4: Typical FT Percentage Production

Source: Unpublished Final Year Project in Petroleum

Engineering Department, FUTO, 2014

For instance, naphtha fraction may be further upgraded to gasoline with catalytic reforming or alternatively, the naphtha could be used as steam cracker for olefins production. While a much higher yield of diesel can be achieved when wax is hydro-cracked. Hydro-cracking requires additional hydrogen, which can be produced from a syngas side-stream that is completely shifted to hydrogen via the water-gas-shift (WGS) reaction:

$\mathrm{CO}+\mathrm{H}_{2} \mathrm{O} \longrightarrow \mathrm{CO}_{2}+\mathrm{H}_{2}$

The GTL processes in operation converts, between 8,500 to 12,000 cubic feet of gas into 1 barrel $\left(0.16 \mathrm{~m}^{3}\right)$ of liquid synthetic fuels depending on the plant. The commonly accepted is that 10,000 cu. ft. ( $286 \mathrm{~m}^{3}$ ) converts to one barrel.

\subsection{Reaction Mechanism of the Direct GTL Production Processes}

The various direct GTL routes presently being explored involves (a) the conversion of a pressurized mixture of methane and oxygen at moderate temperatures (b) the catalytic coupling (oxidative coupling) of methane and an oxidant in the presence of a catalyst at moderate temperatures (c) the catalytic reaction of methane with a mixture of hydrogen chloride and oxygen $(\mathrm{d})$ indirect oxidation of methane to ethylene at high temperatures and (e) contacting methane with a catalyst at a relatively high temperature to form ethylene (Shad and Durr, 2007) (f) chemical oxidative coupling of 
methane/ methane electrochemical oxidative coupling (Silva and Miranda, 2016), in which ethylene can be generated using either the chemical oxidative coupling of methane

$\mathrm{CH}_{4}+1 /{ }_{2} \mathrm{O}_{2} 1 / 2 \longrightarrow \mathrm{C}_{2} \mathrm{H}_{4}+\mathrm{H}_{2} \mathrm{O}$ Or

the methane electrochemical oxidative coupling, in which solid oxide fuel cell (SOFC) reactor is used for the direct conversion of methane into $\mathrm{C}_{2}$ type hydrocarbons via methyl radicals $\left(\mathrm{CH}_{3}{ }^{*}\right)$, which couples to $\mathrm{C}_{2} \mathrm{H}_{6}$ and further dehydrogenated to $\mathrm{C}_{2} \mathrm{H}_{4}$, figure 18 .

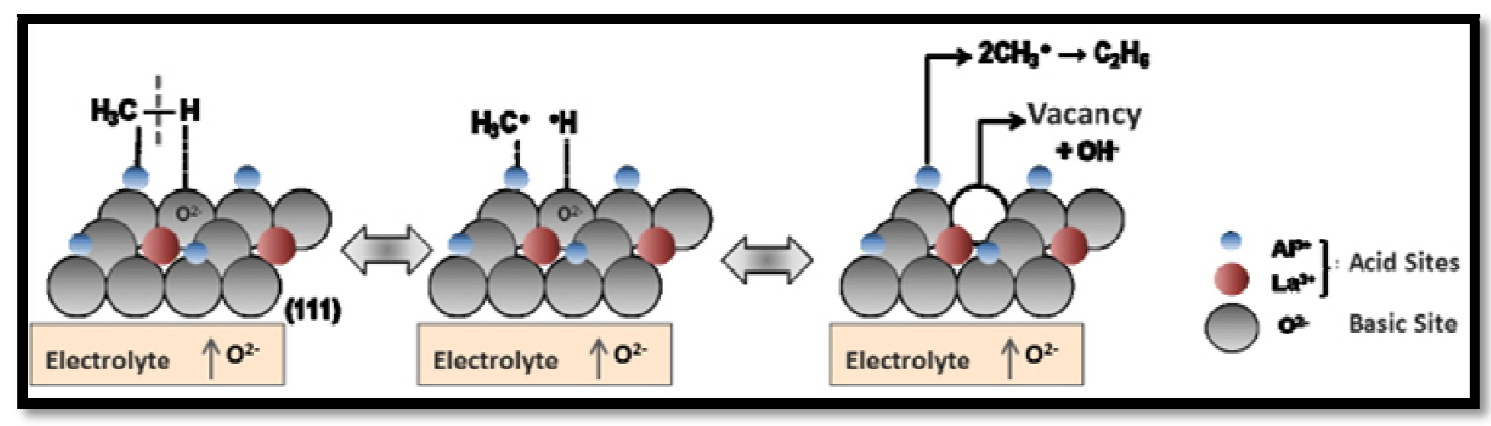

Figure 18: Schematic Representation Proposed for the Methane Electrochemical

Oxidative Coupling Reaction in a SOFC-Type Reactor

Source: Adapted From Silva and Miranda, 2016

- Methane partial oxidation anodic reaction

$2 \mathrm{CH}_{4}+2 \mathrm{O}^{2-} \longrightarrow 2 \mathrm{C}_{2} \mathrm{H}_{4}+2 \mathrm{H}_{2} \mathrm{O}+4 \mathrm{e}$ - (ethylene formation)

$2 \mathrm{CH}_{4}+\mathrm{O}^{2-} \longrightarrow \mathrm{C}_{2} \mathrm{H}_{6}+\mathrm{H}_{2} \mathrm{O}+2 \mathrm{e}$ - (ethane formation) and

(ii) Cathodic reaction

$2 \mathrm{O}_{2}+8 \mathrm{e}-\mathrm{M} \longrightarrow \mathrm{O}^{2-}$ (formation of oxygen ions $\mathrm{O}^{2-}$ )

The new single-step, low temperature gas to liquid technology process being developed by(PEERI), which uses specific ionic liquids (IL) as a medium to develop a catalyst system that gives the highest conversion of methane to methanol for low temperature methane conversion process, figure 6.

\section{Chemical Reaction Mechanisms for the Proposed Direct GTL Models}

The chemical reaction mechanisms for the four proposed direct GTL models, in this research study are developed based on the following scientific fundamentals:

- Any gas can be liquefied at atmospheric pressure if it is cooled sufficiently (Heys, 1980). Every gas has its critical temperature, and if the gas is at any temperature below its critical and pressure is gradually increased, the molecules come closer together, and attract each other more strongly, hence liquefy. Also, On the other hand, any gas which has a critical temperature above room temperature, can be liquefied by pressure alone e.g. carbon dioxide, ammonia, chlorine, hydrogen chloride, hydrogen sulphide and sulphur dioxide.

- It is technically feasible to synthesize almost any hydrocarbon from any other. One of the useful features of organic chemistry is the ease of interconversion of functional groups, which makes it relatively easy to synthesize a whole range of new compounds starting from a given compound and using simple reactions (Bamkole and Ogunkoya, 1978), figure 19. 


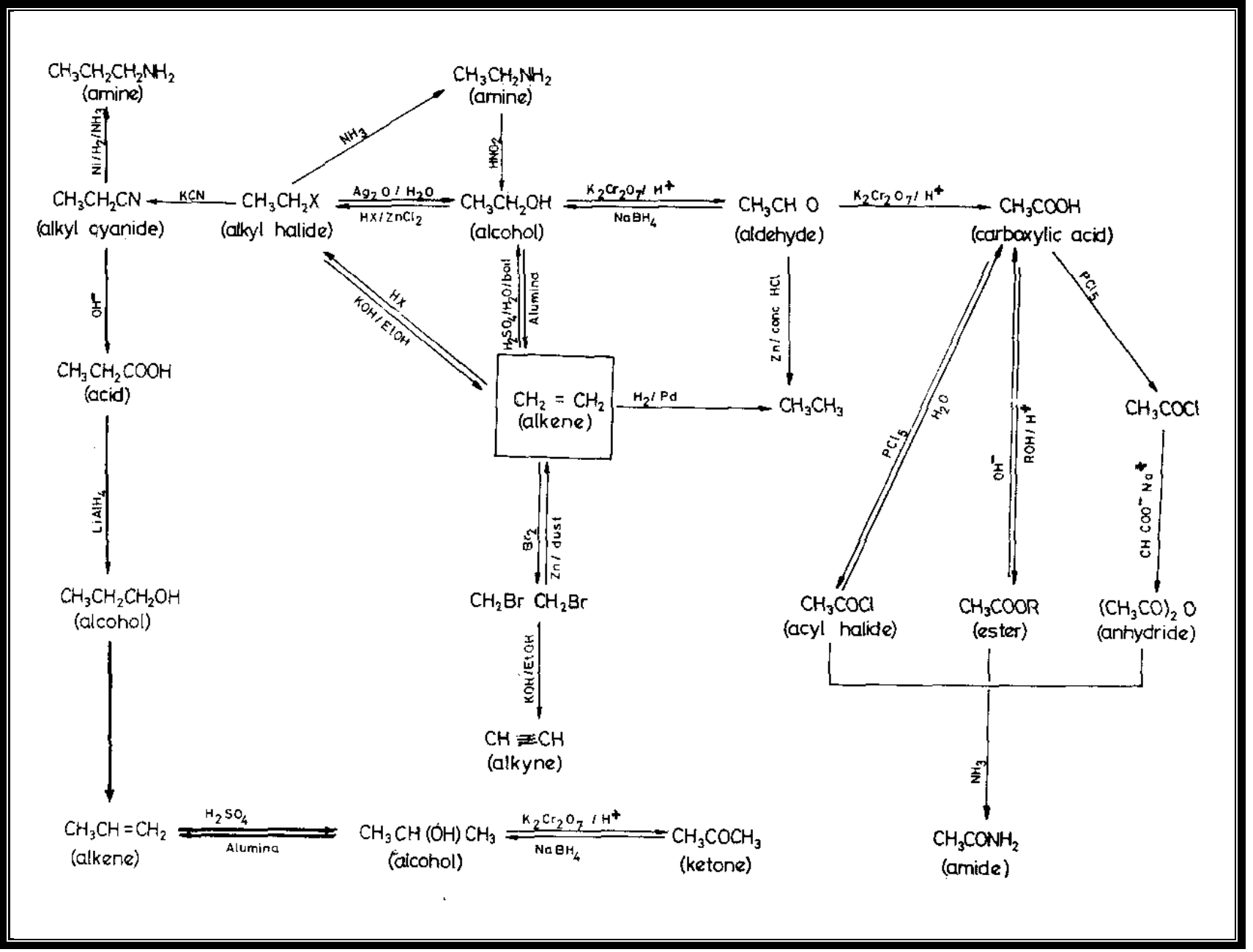

Figure 19: Interconversion of functional groups

Source: Adapted from Bamkole and Ogunkoya, 1978

(c) Thermal cracking of methane yields carbon and hydrogen(Block et al., 1995):
$\mathrm{CH}_{4}$
$\mathrm{C}+2 \mathrm{H}_{2}$

(d) Cracking of methane at temperature of over $1200^{\circ}$ Cyields ethyne 'acetylene' (Bamkole and Ogunkoya, 1978):
$2 \mathrm{CH}_{4}$
$\mathrm{C}_{2} \mathrm{H}_{2}$ (ethyne) $+3 \mathrm{H}_{2}$
$\mathrm{C}_{2} \mathrm{H}_{2}+\mathrm{H}_{2}$
$\mathrm{C}_{2} \mathrm{H}_{4}$ (ethene)

and $\mathrm{C}_{2} \mathrm{H}_{2}+\mathrm{C}_{2} \mathrm{H}_{2}+\mathrm{C}_{2} \mathrm{H}_{2} \quad \mathrm{G}_{6} \mathrm{H}_{6}$ (aromatic)

\{i.e. $\mathrm{CH} \equiv \mathrm{CH}+\mathrm{CH} \equiv \mathrm{CH}+\mathrm{CH} \equiv \mathrm{CH} \longrightarrow \mathrm{C}_{6} \mathrm{H}_{6}$ \}

- It is possible to generate hydrocarbons building blocks $\left(-\mathrm{CH}_{2}-\right)$ or hydrocarbons chain extension from ethene, in presence of a catalyst which can produce different compounds of hydrocarbons (liquids) via polymerization of the hydrocarbon building block, figure 20 .

$\mathrm{CH}_{2}=\mathrm{CH}_{2}+\mathrm{CH}_{2}=\mathrm{CH}_{2}+\mathrm{CH}_{2}=\mathrm{CH}_{2} \longrightarrow \mathrm{CH}_{2}-\mathrm{CH}_{2}-\mathrm{CH}_{2}-\mathrm{CH}_{2}-\mathrm{CH}_{2}-\mathrm{CH}_{2}-$

That is,

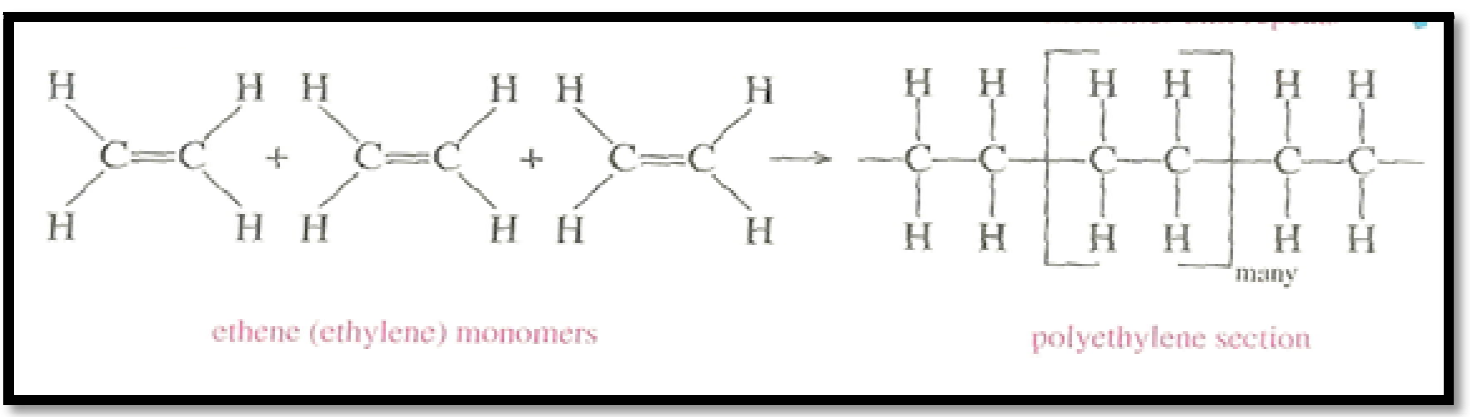

Figure 20: Polymerization of Ethylene to Polyethylene

Source: Adapted from Timberlake, 2006

- A selectivity catalyst can be used to chemically break one or two $\mathrm{C}-\mathrm{H}$ bonds of the methane molecule to generated radicals and $\mathrm{H}_{2}$ molecules. The common radicals generated from methane are, methyl radicals $\left(\mathrm{CH}_{3}{ }^{*}\right)$, methylene 
radicals $\left({ }^{*} \mathrm{CH}_{2} *\right)$, hydrogen radicals $\left(\mathrm{H}^{*}\right)$. Radicals are highly reactive (i.e. behaving as electrophiles) because of their electron-deficiency.

The chemical reaction models for each of the four proposed direct GTL options are based on the synergy/ synthesis (i.e. combined application or effects of any two or more) of the above stated fundamental scientific processes.

4.1. Scenario 1: Direct Methanol $\left(\mathrm{CH}_{3} \mathrm{OH}\right)$ Production by Controlled Oxidation Of Methane

The equation for the production of methanol via controlled oxidation of methane is
$4 \mathrm{CH}_{4}+3 \mathrm{O} 2$
formaldehyde(methanal)
$+\quad 2 \mathrm{H}_{2} \mathrm{O}$
Methanol
water

Many important reactions of aldehydes result from the high polarity of the $\mathrm{C}=\mathrm{O}$ bond which leaves the carbon atom electron - deficient and hence susceptible to attack by nucleophiles.

Polymerization of methanal at room temperature yields a white solid called trioxan with molecular formular $\left(\mathrm{CH}_{2} \mathrm{O}\right)_{3}$ melting point $61-62{ }^{\circ} \mathrm{C}$, (Bamkole and Ogunkoya, 1978):

Hydrogenation: $\mathrm{CH}_{2} \mathrm{O}+\mathrm{H}_{2} \longrightarrow \mathrm{CH}_{3} \mathrm{OH}$

Hydrolysis: $2 \mathrm{H}_{2} \mathrm{O} \longrightarrow 2 \mathrm{H}_{2} \quad+\mathrm{O} 2$

Both oxygen $\left(\mathrm{O}_{2}\right)$ and surplus hydrogen $\left(\mathrm{H}_{2}\right)$ becomes recycled gas and are sent back to the respective appropriate feed stream, figure 21.

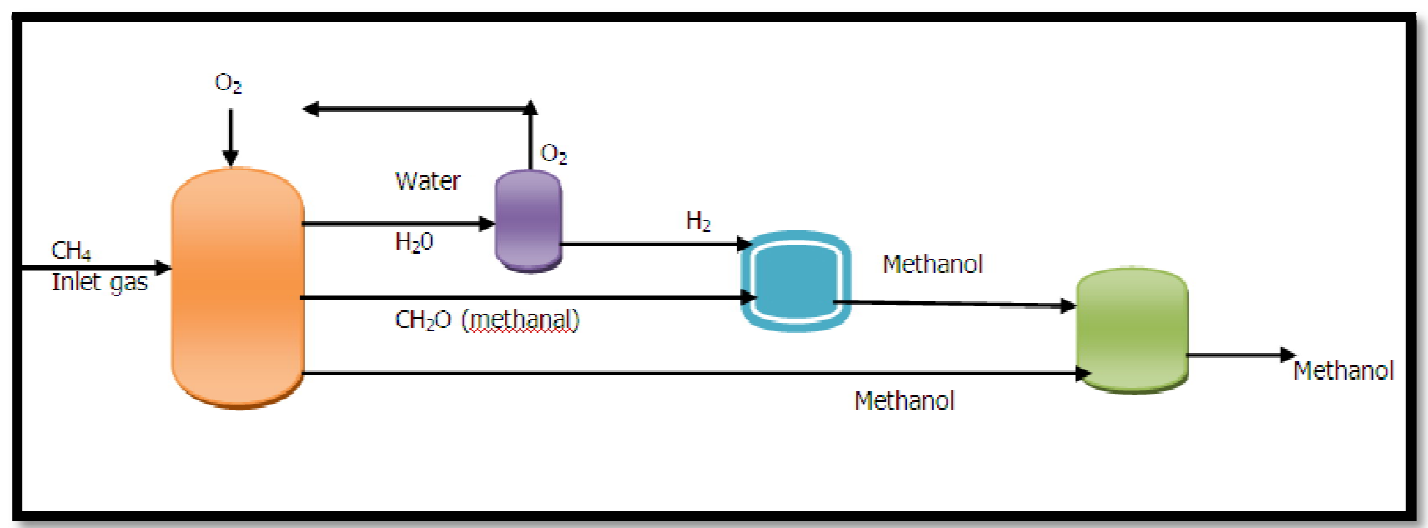

Figure 21: Process Flow Diagram for Methanol

Production by Controlled Oxidation of Methane

The methanol is converted to gasoline, by using mobile process (zeolite catalyst such as ZSM-5):

$2 \mathrm{CH}_{3} \mathrm{OH} \longrightarrow \mathrm{CH}_{3} \mathrm{OCH}_{3}+\mathrm{H}_{2} \mathrm{O}$ i.e. methanol dehydrated to give dimethyl ether

$\mathrm{CH}_{3} \mathrm{OCH}_{3} \longrightarrow \mathrm{C}_{2} \mathrm{H}_{4}+\mathrm{H}_{2} \mathrm{O}$ (further dehydration over zeolite catalyst)

The $\mathrm{C}_{2} \mathrm{H}_{4}$ is polymerized and hydrogenated to give gasoline with hydrocarbons of five to more carbon atoms making up $80 \%$ of the fuel by weight (Wikipedia-GTL), figure 22 .

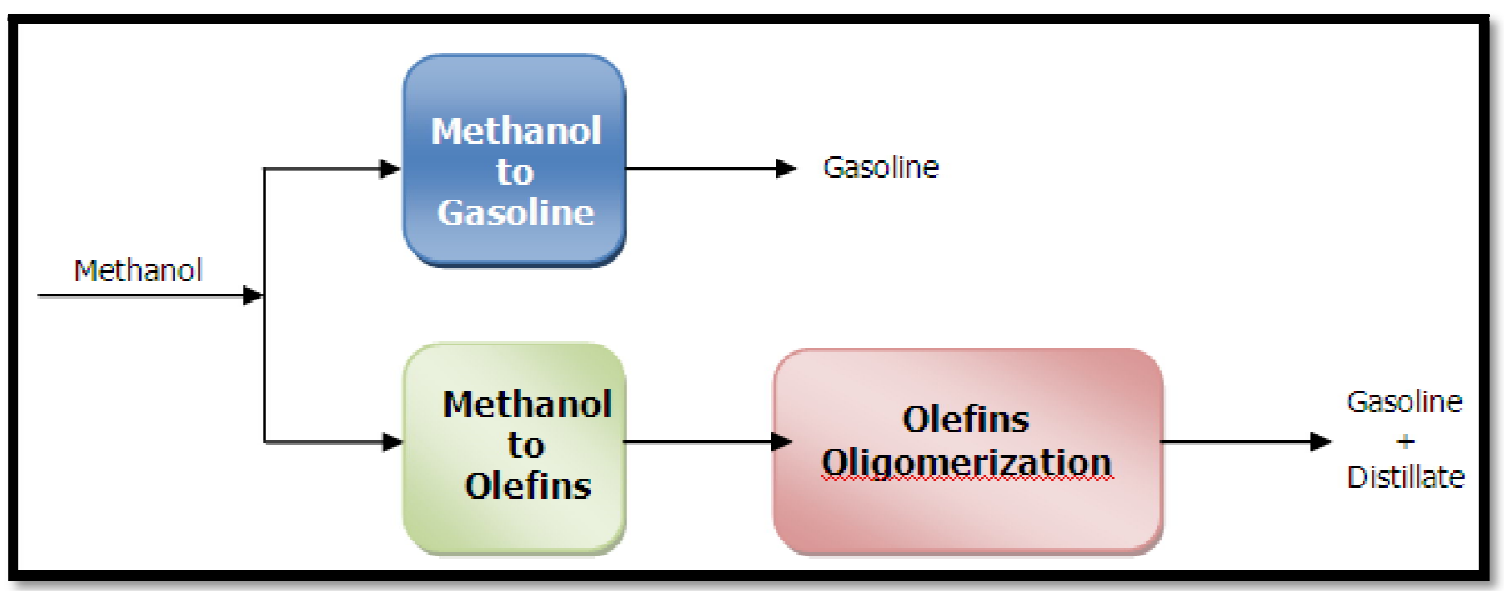

Figure 22: Methanol Is Conversion to Gasoline by Mobil Process

Figure 23 shows the various products from methanol, such as clean fuels and green chemicals. 


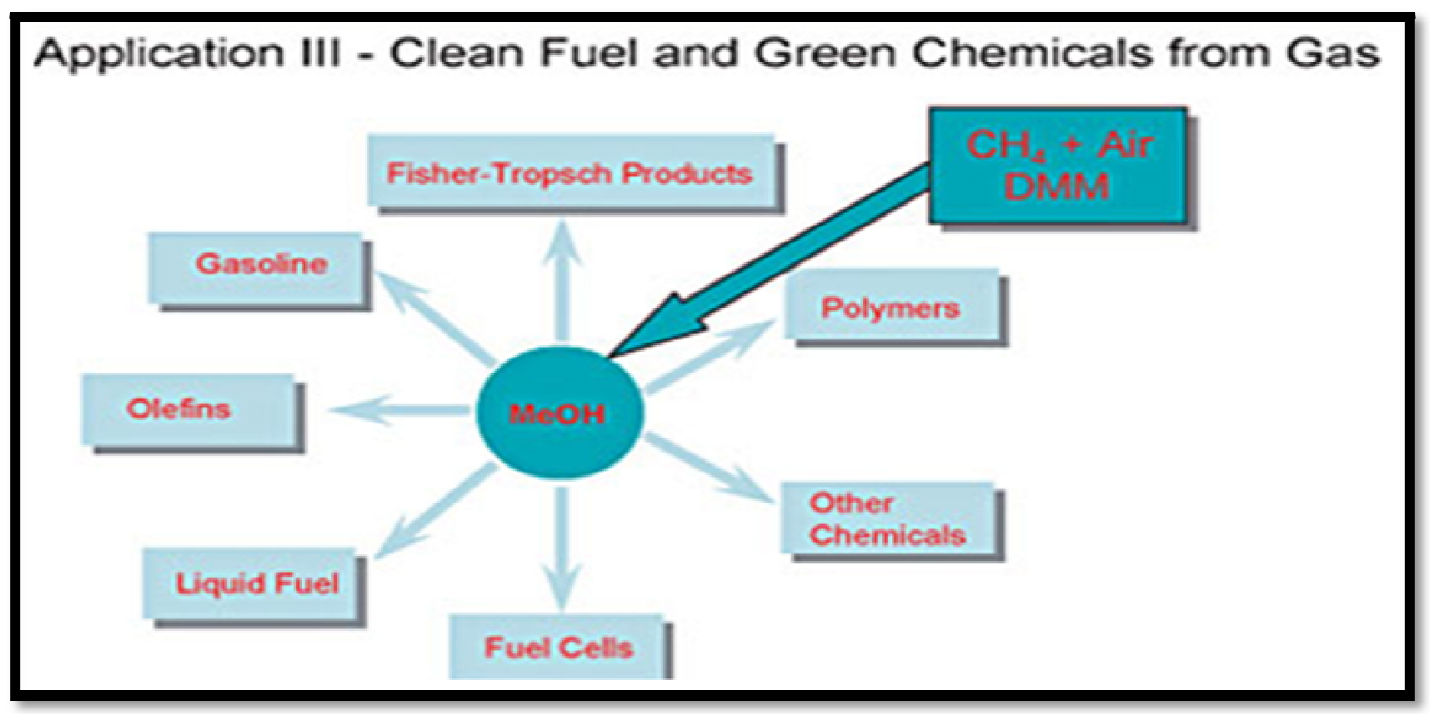

Figure 23: Clean Fuel and Green Chemicals from Natural Gas (Methane) Via Methanol Source: Adapted from PEERI

4.2. Scenario 2: Direct Generation of Olefin or Aromatic Hydrocarbons from Methane (Thermo-Chemical Process) Cracking of methane at temperature of over $1200{ }^{\circ} \mathrm{C}$ yields acetylene (Bamkole and Ogunkoya, 1978)
(i) Addition reaction:
$\mathrm{C}_{2} \mathrm{H}_{2}+\mathrm{H}_{2}$
$\longrightarrow \mathrm{C}_{2} \mathrm{H}_{2}+3 \mathrm{H}_{2}$
catalyst, room temp.
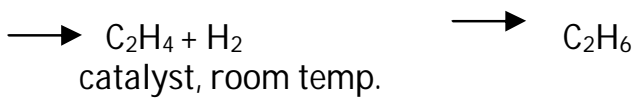

Finely divided palladium or finely divided platinum is used as catalyst.

(ii) Polymerization of acetylene, yields benzene (aromatic):

$\mathrm{CH} \equiv \mathrm{CH}+\mathrm{CH} \equiv \mathrm{CH}+\mathrm{CH} \equiv \mathrm{CH} \longrightarrow \mathrm{C}_{6} \mathrm{H}_{6}$

Applying the upgrade similar to FT-GTL to the aromatic yields gasoline, diesel etc.

(iii) $\quad \mathrm{C}_{2} \mathrm{H}_{2}+\mathrm{H}_{2} \longrightarrow \mathrm{C}_{2} \mathrm{H}_{4}$ (ethene)

and polymerization of ethene plus hydrogen $\mathrm{H}_{2}$ yields gasoline, kerosene, diesel etc.For example, gasoline component is obtained as follows.

$\mathrm{CH}_{2}=\mathrm{CH}_{2}+\mathrm{CH}_{2}=\mathrm{CH}_{2}+\mathrm{CH}_{2}=\mathrm{CH}_{2} \longrightarrow \mathrm{CH}_{2}-\mathrm{CH}_{2}-\mathrm{CH}_{2}-\mathrm{CH}_{2}-\mathrm{CH}_{2}-\mathrm{CH}_{2}-$

and $-\mathrm{CH}_{2}-\mathrm{CH}_{2}-\mathrm{CH}_{2}-\mathrm{CH}_{2}-\mathrm{CH}_{2}-\mathrm{CH}_{2}-+\mathrm{H}_{2} \longrightarrow \mathrm{C}_{6} \mathrm{H}_{14}$ i.e. $\left\{\mathrm{H}-\left(\mathrm{CH}_{2}\right)_{6}-\mathrm{H}\right\}$, figure 24 . 
Formulas and Physical Properties of the Unbranched Alkanes

\begin{tabular}{llcrrc} 
Alkane & \multicolumn{1}{c}{ Structure } & Formula & $\begin{array}{c}\text { Boiling } \\
\text { Point }\left({ }^{\circ} \mathrm{C}\right)\end{array}$ & $\begin{array}{c}\text { Melting } \\
\text { Point }\left({ }^{\circ} \mathrm{C}\right)\end{array}$ & Density \\
\hline methane & $\mathrm{H}-\mathrm{CH}_{2}-\mathrm{H}$ & $\mathrm{CH}_{4}$ & -164 & -183 & 0.55 \\
ethane & $\mathrm{H}-\left(\mathrm{CH}_{2}\right)_{2}-\mathrm{H}$ & $\mathrm{C}_{2} \mathrm{H}_{6}$ & -89 & -183 & 0.51 \\
propane & $\mathrm{H}-\left(\mathrm{CH}_{2}\right)_{3}-\mathrm{H}$ & $\mathrm{C}_{3} \mathrm{H}_{8}$ & -42 & -189 & 0.50 \\
butane & $\mathrm{H}-\left(\mathrm{CH}_{2}\right)_{4}-\mathrm{H}$ & $\mathrm{C}_{4} \mathrm{H}_{10}$ & 0 & -138 & 0.58 \\
pentane & $\mathrm{H}-\left(\mathrm{CH}_{2}\right)_{5}-\mathrm{H}$ & $\mathrm{C}_{5} \mathrm{H}_{12}$ & 36 & -130 & 0.63 \\
hexane & $\mathrm{H}-\left(\mathrm{CH}_{2}\right)_{6}-\mathrm{H}$ & $\mathrm{C}_{6} \mathrm{H}_{14}$ & 69 & -95 & 0.66 \\
heptane & $\mathrm{H}-\left(\mathrm{CH}_{2}\right)_{7}-\mathrm{H}$ & $\mathrm{C}_{7} \mathrm{H}_{16}$ & 98 & -91 & 0.68 \\
octane & $\mathrm{H}-\left(\mathrm{CH}_{2}\right)_{8}-\mathrm{H}$ & $\mathrm{C}_{8} \mathrm{H}_{18}$ & 126 & -57 & 0.70 \\
nonane & $\mathrm{H}-\left(\mathrm{CH}_{2}\right)_{9}-\mathrm{H}$ & $\mathrm{C}_{9} \mathrm{H}_{20}$ & 151 & -51 & 0.72 \\
decane & $\mathrm{H}-\left(\mathrm{CH}_{2}\right)_{10}-\mathrm{H}$ & $\mathrm{C}_{10} \mathrm{H}_{22}$ & 174 & -30 & 0.73 \\
undecane & $\mathrm{H}-\left(\mathrm{CH}_{2}\right)_{11}-\mathrm{H}$ & $\mathrm{C}_{11} \mathrm{H}_{24}$ & 196 & -26 & 0.74 \\
dodecane & $\mathrm{H}-\left(\mathrm{CH}_{2}\right)_{12}-\mathrm{H}$ & $\mathrm{C}_{12} \mathrm{H}_{26}$ & 216 & -10 & 0.75 \\
tridecane & $\mathrm{H}-\left(\mathrm{CH}_{2}\right)_{13}-\mathrm{H}$ & $\mathrm{C}_{13} \mathrm{H}_{28}$ & 235 & -5 & 0.76 \\
tetradecane & $\mathrm{H}-\left(\mathrm{CH}_{2}\right)_{14}-\mathrm{H}$ & $\mathrm{C}_{14} \mathrm{H}_{30}$ & 254 & 6 & 0.76 \\
pentadecane & $\mathrm{H}-\left(\mathrm{CH}_{2}\right)_{15}-\mathrm{H}$ & $\mathrm{C}_{15} \mathrm{H}_{32}$ & 271 & 10 & 0.77 \\
hexadecane & $\mathrm{H}-\left(\mathrm{CH}_{2}\right)_{16}-\mathrm{H}$ & $\mathrm{C}_{16} \mathrm{H}_{34}$ & 287 & 18 & 0.77 \\
heptadecane & $\mathrm{H}-\left(\mathrm{CH}_{2}\right)_{17}-\mathrm{H}$ & $\mathrm{C}_{17} \mathrm{H}_{36}$ & 303 & 23 & 0.76 \\
octadecane & $\mathrm{H}-\left(\mathrm{CH}_{2}\right)_{18}-\mathrm{H}$ & $\mathrm{C}_{18} \mathrm{H}_{38}$ & 317 & 28 & 0.76 \\
nonadecane & $\mathrm{H}-\left(\mathrm{CH}_{2}\right)_{19}-\mathrm{H}$ & $\mathrm{C}_{19} \mathrm{H}_{40}$ & 330 & 32 & 0.78 \\
eicosane & $\mathrm{H}-\left(\mathrm{CH}_{2}\right)_{20}-\mathrm{H}$ & $\mathrm{C}_{20} \mathrm{H}_{42}$ & 343 & 37 & 0.79 \\
triacontane & $\mathrm{H}-\left(\mathrm{CH}_{2}\right)_{30}-\mathrm{H}$ & $\mathrm{C}_{30} \mathrm{H}_{62}$ & $>450$ & 66 & 0.81 \\
\hline \multirow{5}{*}{} & & & ${ }^{2}$ Densities are given in g/mL at $200^{\circ} \mathrm{C}$ \\
\hline
\end{tabular}

Figure 24: Component of Alkane Hydrocarbons That Constitutes Gasoline, Kerosene, Diesel Etc. Source: Adapted From the Images of Hydrocarbon Components

Figure 25 show the Proposed Thermo - Chemical Process for the generation of synthetic fuel from methane.

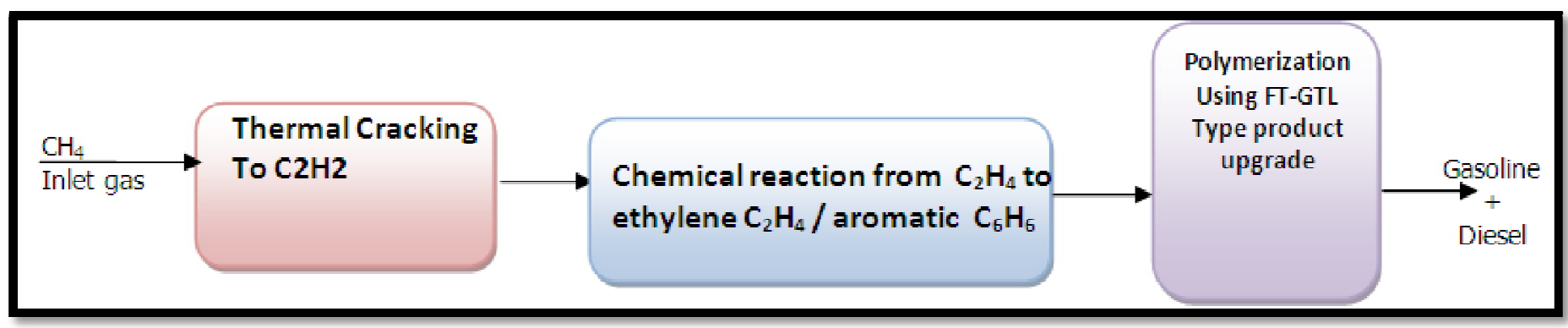

Figure 25: Proposed Thermo - Chemical Process

4.3. Scenario 3: Direct Generation of Radicals $\left(\mathrm{CH}_{3} *\right.$ or $\mathrm{CH}_{2}{ }^{*}, \mathrm{H} *$ and $\mathrm{H}_{2}$ Molecules from Methane (Physio-Chemical Process)

Figure 26, shows the general cooling and heating curve pattern for physical change of states from gaseous to liquid to solid and vice versa. While figure 27 shows the phase diagram pattern for water $\left(\mathrm{H}_{2} \mathrm{O}\right)$, methane $\left(\mathrm{CH}_{4}\right)$ and nitrogen $\left(\mathrm{N}_{2}\right)$. 


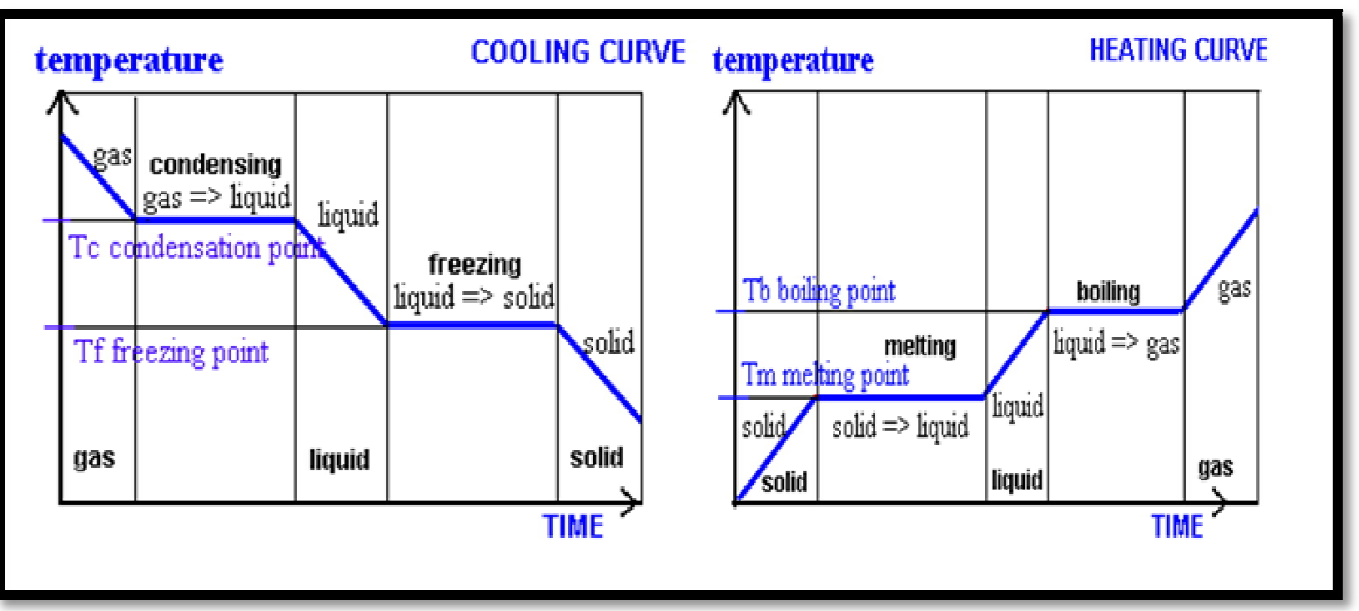

Figure 26: General Pattern of Cooling and Heating Curves for Physical Change of States Source: Adapted from the Images of Solid, Liquid and Gas

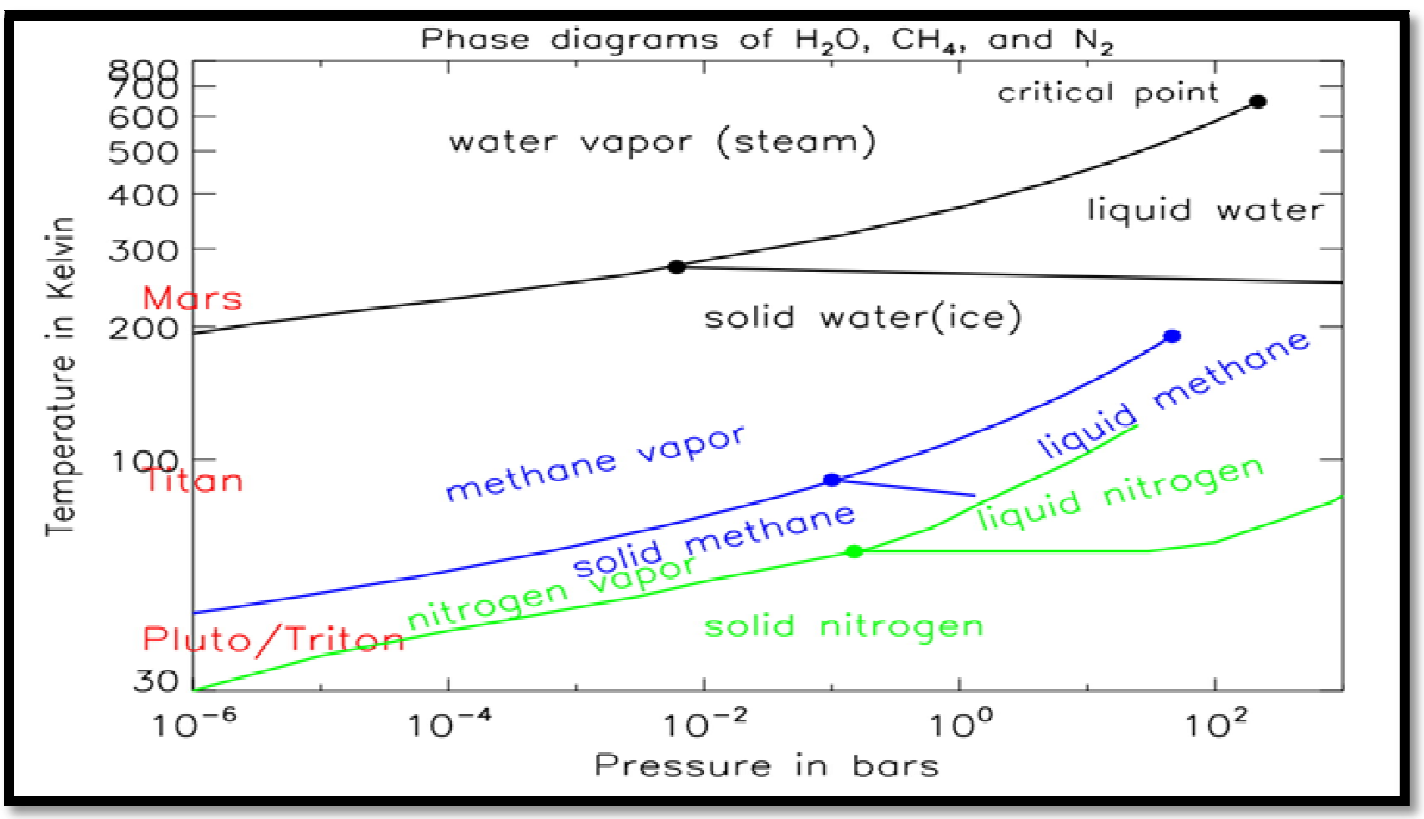

Figure 27: Phase Diagram Pattern for Water $\left(\mathrm{H}_{2} \mathrm{O}\right)$, Methane $\left(\mathrm{CH}_{4}\right)$ and Nitrogen $\left(\mathrm{N}_{2}\right)$. Source: Adapted from Judith C. Perez

Table 5 shows the Comparison of some physical properties of water and methane, while figures 28 and 29 shows the Cooling and Heating Curves for the physical change of states, for water and methane respectively.

\begin{tabular}{|c|c|c|}
\hline Property & Water & Methane \\
\hline Boiling point & $100^{\circ} \mathrm{C}\left(+212^{\circ} \mathrm{F}\right)$ & $-161.5^{\circ} \mathrm{C}$ (Boiling pt. at 14.696 psia and $\left.-260^{\circ} \mathrm{F}\right)$ \\
\hline Melting point & $0{ }^{\circ} \mathrm{C}\left(+32^{\circ} \mathrm{F}\right)$ & $-182.5^{\circ} \mathrm{C}\left(\right.$ Freezing pt. at 14.696 psia and $\left.-297{ }^{\circ} \mathrm{F}\right)$ \\
\hline Critical temperature & $\begin{array}{c}374^{\circ} \mathrm{C}\left(+705^{\circ} \mathrm{F}\right) \text { around } \\
647 \mathrm{~K}\end{array}$ & $-82.3^{\circ} \mathrm{C}\left(-116.68{ }^{\circ} \mathrm{F} \mathrm{or} \mathrm{190.8 \textrm {K } )}\right.$ \\
\hline Critical pressure & $\begin{array}{c}3200 \mathrm{psia}(218 \mathrm{~atm}) \text { i.e. } \\
22.064 \mathrm{Mpa}\end{array}$ & $667.8 \mathrm{psia}(45.79 \mathrm{~atm})$ or $4,640 \mathrm{kPa}$ \\
\hline Critical volume & $0.056 \mathrm{~m}^{3} \mathrm{kmol}-1$ & $0.0991 \mathrm{ft} 3 / \mathrm{lb}$ \\
\hline $\begin{array}{c}\text { State at room temperature } \\
68^{\circ} \mathrm{F}\left(20^{\circ} \mathrm{C}\right)\end{array}$ & Liquid & Gas \\
\hline
\end{tabular}

Table 5: Comparison of Some Physical Properties of Water and Methane 


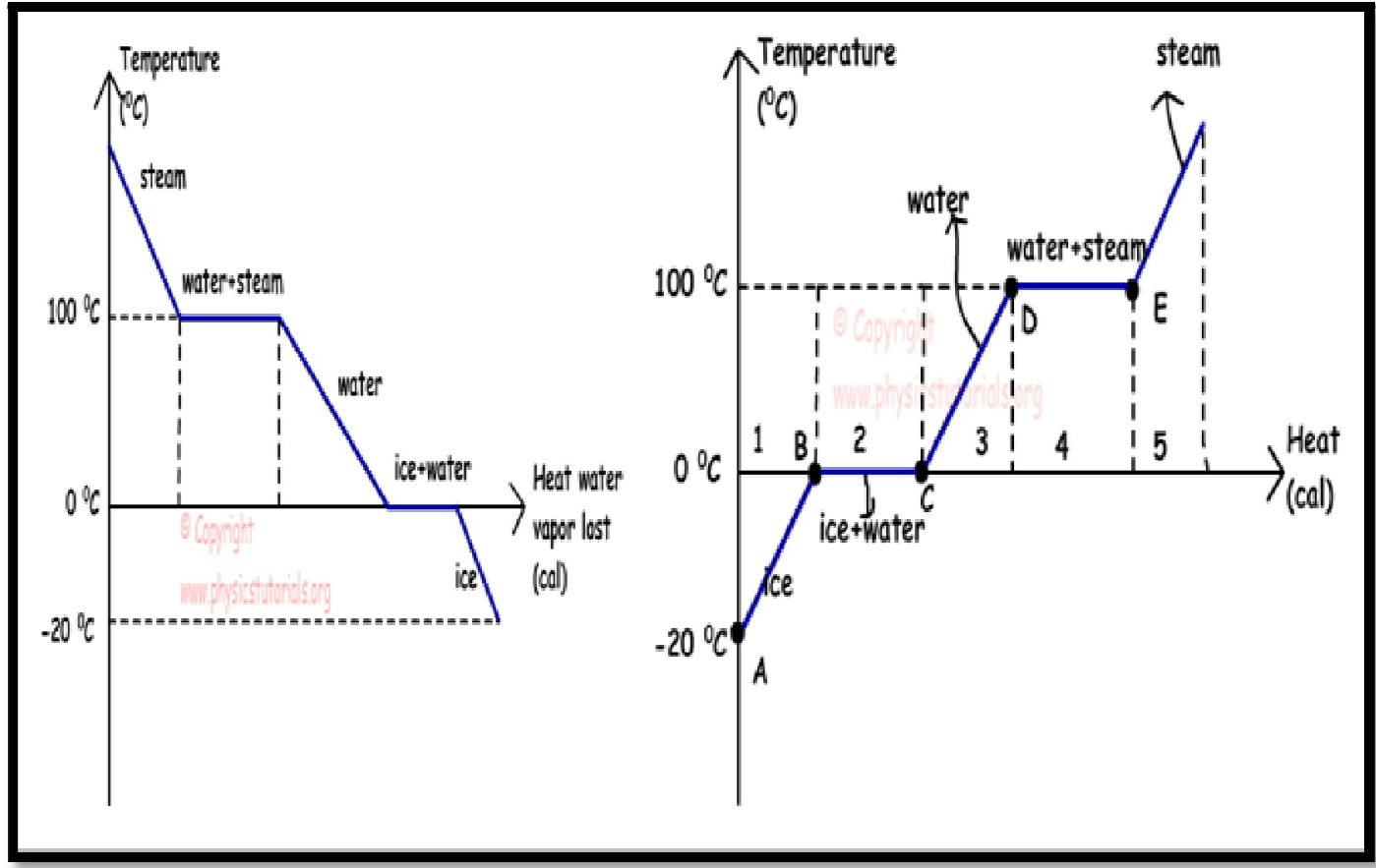

Figure 28: Cooling and Heating Curves for Water Physical Change of States Source: Adapted from Physics Tutorial Online

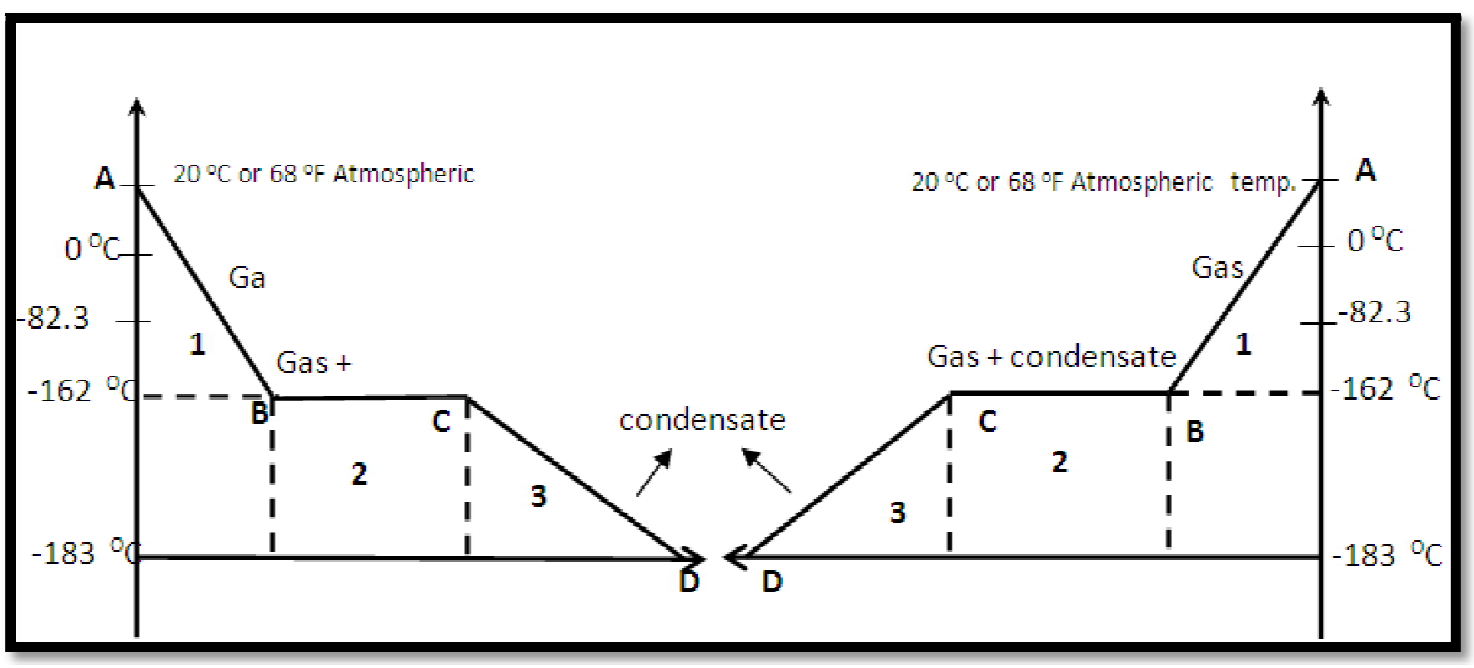

Figure 29: Cooling and Heating Curves for Methane (Natural Gas)Physical Change of States

This graph (figure 29) shows the relationship between temperature and heat, when methane gas is cooled to its condensation temperature. At point A, normal temperature $20{ }^{\circ} \mathrm{C}(68 \mathrm{oF})$ and atmospheric pressure 14.7 psia, it is gaseous methane. Within the interval of points $\mathrm{A}$ and $\mathrm{B}$, it loses heat to cool from $20^{\circ} \mathrm{C}$ to its critical point $-82.3^{\circ} \mathrm{C}\left(-117^{\circ} \mathrm{F}\right)$ and further to point $\mathrm{B}$, its condensation/ boiling point $-162{ }^{\circ} \mathrm{C}\left(-260^{\circ} \mathrm{F}\right)$, and the gas starts to condense. Between points $\mathrm{B}$ and $\mathrm{C}$, there is no change in temperature, because its state is changing from gas to condensed liquid. At point $\mathrm{C}$, the condensation process is completed and it becomes liquefied methane (i.e. liquefied natural gas (LNG). Between points C and D, it remains condensate liquid, but if cooling continues below $-183^{\circ} \mathrm{C}$, its freezing/ melting point, the condensate will start to freeze.

The proposed direct Physcio- chemical GTL process is accomplished by first condensing the gas physically and then, apply a selectivity catalyst to chemically break one or two C-H bonds of the methane to $\mathrm{CH}_{3}{ }^{*} \mathrm{or}_{\mathrm{CH}}{ }^{*}$, $\mathrm{H}^{*}$ radicals and $\mathrm{H}_{2}$ molecules. It is subsequently allowed to undergo Joule-Thomson expansion to increase the temperature to between -89 ${ }^{\circ} \mathrm{C}$ and $20{ }^{\circ} \mathrm{C}$, as well as enable the radicals to polymerize in similar manner to the FT-GTL process, to yield desired products, figure 24 .

Thus, with the help of selectivity catalyst, special products such as gasoline/naphtha $\left(\mathrm{C}_{5}\right.$ to $\left.\mathrm{C}_{10}\right)$, and kerosene/ diesel $\left(\mathrm{C}_{11}\right.$ to $\left.\mathrm{C}_{20}\right)$ are produced. For instance, $\mathrm{C}_{5} \mathrm{H}_{12}$ could be produced through any of the following catalytic selectivity radical's combination reactions:

$\mathrm{CH}_{2}+\mathrm{CH}_{2}+\mathrm{CH}_{2}+\mathrm{CH}_{2}+\mathrm{CH}_{2}+\mathrm{H}_{2} \mathrm{C}_{5} \mathrm{H}_{12} \longrightarrow \mathrm{CH}_{3}+\mathrm{CH}_{2}+\mathrm{CH}_{2}+\mathrm{CH}_{2}+\mathrm{CH}_{3} \mathrm{C}_{5} \mathrm{H}_{12} \longrightarrow \mathrm{H}+\mathrm{CH}_{2}+\mathrm{CH}_{2}+\mathrm{CH}_{2}+\mathrm{CH}_{2}+\mathrm{CH}_{2}+$ $\mathrm{H} \mathrm{C}_{5} \mathrm{H}_{12}$

This approach can be a second stage operation to the current liquefied natural gas (LNG) process (e.g. cascade cycle), figure 30 or the compressed natural gas (CNG) process, figure 31, for conversion to liquid fuels. This involves 
catalytic reformation that breaks the C-H bonds of either the LNG or the CNG (i.e. still existing as methane) with catalysts such as oxides of silicon or aluminum, and subsequently the resulting condensate is reduced to room temperature and pressure.

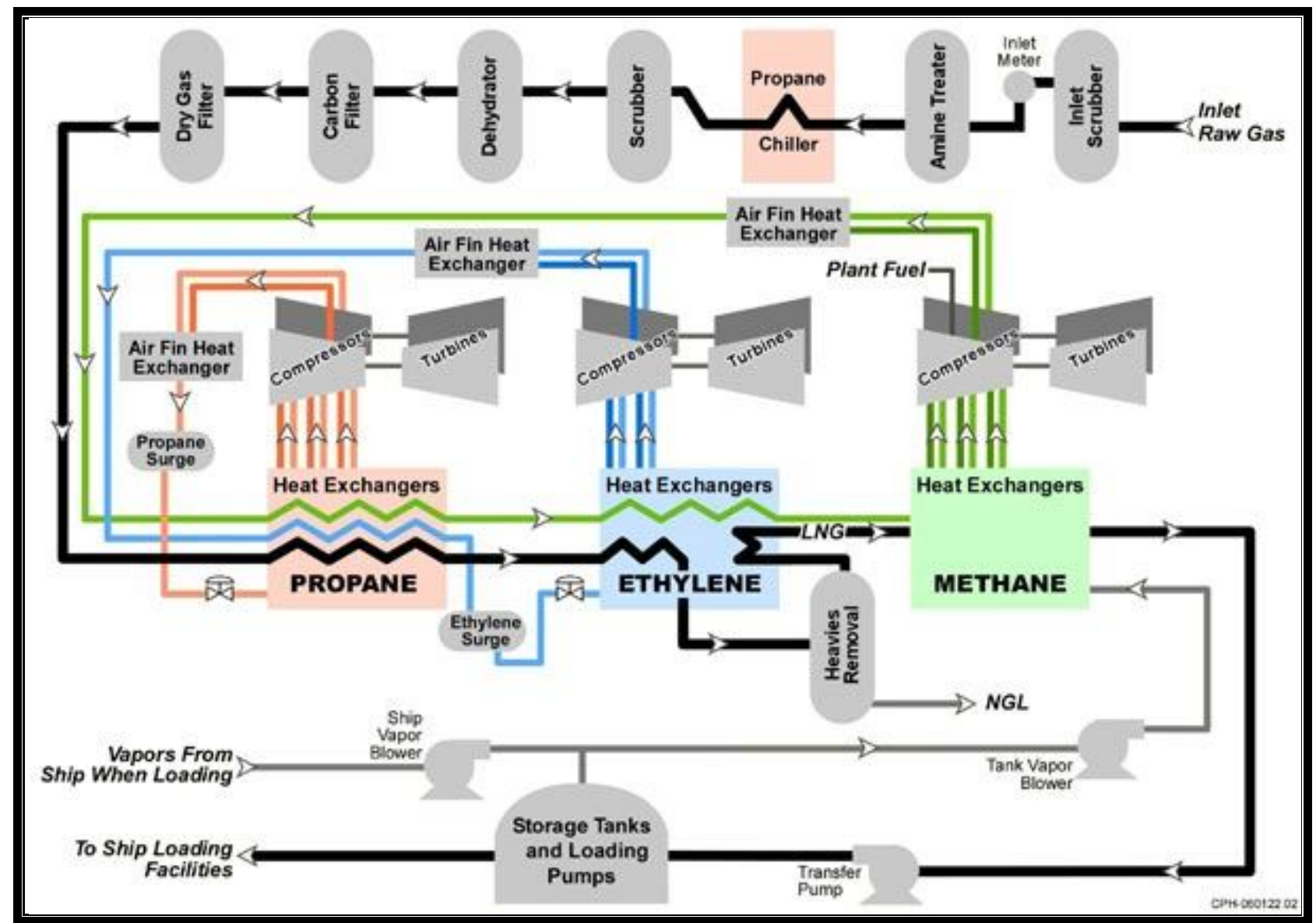

Figure 30: Full Process Layout of the Current LNG Production by Cascade Cycle Source: Adapted from Images of Standard Cascade Liquefaction Cycle

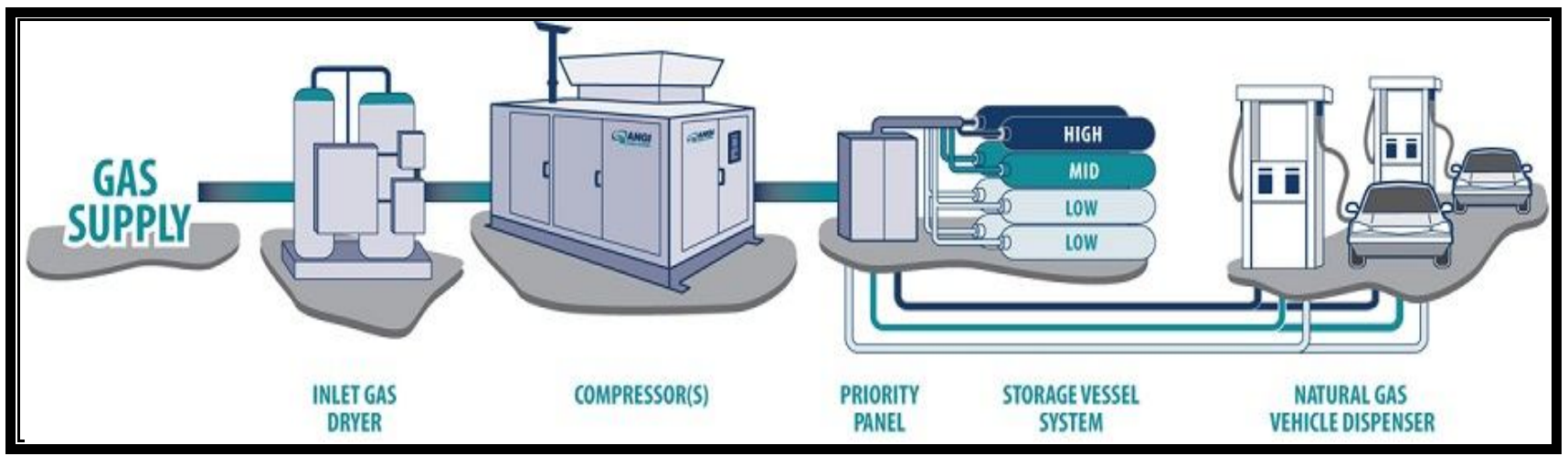

Figure 31: Full Process Layout of the Current CNG Production Process

Source: Adapted from Images of Compressed Natural Gas Processes

Figure 32 show the Proposed Physio - Chemical Process for the generation of synthetic fuel from methane. 


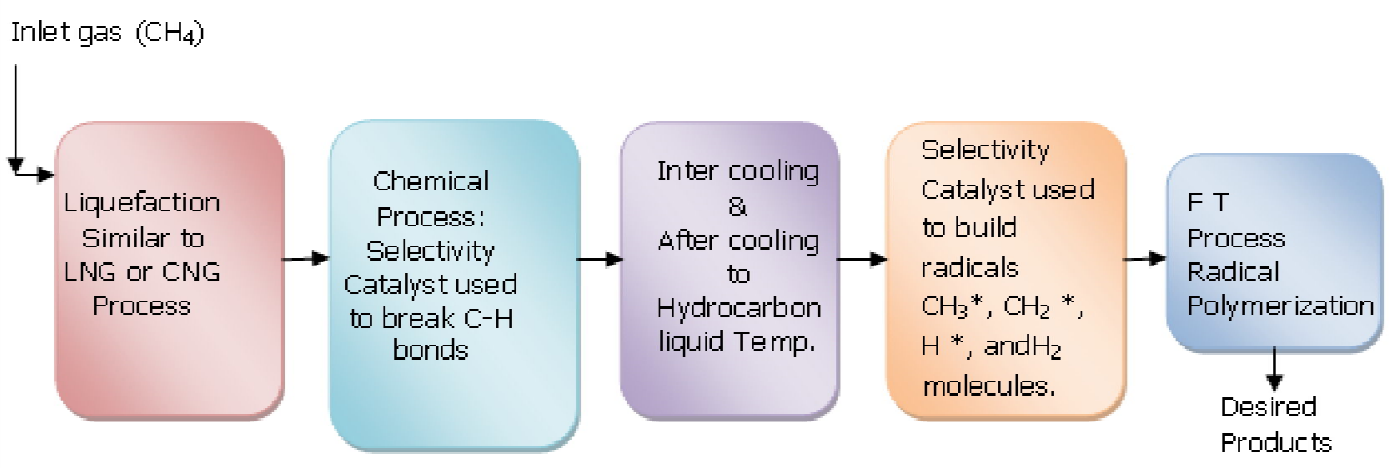

Figure 32: Proposed Physio - Chemical Process

4.4. Scenario 4: Direct generation of hydrocarbon building block (- $\left.\mathrm{CH}_{2}-\right)$ from methane (Thermo-Physio-Chemical Process)

Thermal cracking of methane yields carbon and hydrogen:

$\mathrm{CH}_{4} \mathrm{C}+2 \mathrm{H} 2$

Depending on catalyst selectivity, it is further cracked to

$\mathrm{C}+\mathrm{H}_{2}+\mathrm{H}_{2}$ or $\mathrm{C}+\mathrm{H}+\mathrm{H}+\mathrm{H}+\mathrm{H}$

After cracking the entire stream is compressed 3,000 psia and subsequently converted to hydrocarbons building block (-

$\left.\mathrm{CH}_{2^{-}}\right)$or hydrocarbons chain extension with selectivity catalyst.

(i) $\mathrm{C}+\mathrm{H}_{2} \longrightarrow \mathrm{CH}_{2}$

or

(ii) $\mathrm{C}+\mathrm{H} \longrightarrow \mathrm{CH}$ and $\mathrm{CH}+\mathrm{H} \longrightarrow \mathrm{CH}_{2}$

Figure 33 show the Proposed Thermo - Physio - Chemical Process for the generation of synthetic fuel from methane.

Thereafter, the hydrocarbons building block stream is intercooled, after-cooled and passed through either a twister tube (figure 34) or double joule-thomson valve (figure 35) to reduce pressure to $300 \mathrm{psia}$, then to $10 \mathrm{psia}$, in the presence of a catalyst, to yield different compounds of hydrocarbons (liquids) figure 24, via polymerization of the hydrocarbons building block plus hydrogen $\mathrm{H}_{2}$, as follows:

$\mathrm{CH}_{2}+\mathrm{CH}_{2} \longrightarrow \mathrm{C}_{2} \mathrm{H}_{4}$

$\mathrm{C}_{2} \mathrm{H}_{4}+\mathrm{H}_{2} \longrightarrow \mathrm{C}_{2} \mathrm{H}_{6}$

$\mathrm{CH}_{2}+\mathrm{C}_{2} \mathrm{H}_{4} \longrightarrow \mathrm{C}_{3} \mathrm{H}_{6}$

$\mathrm{C}_{3} \mathrm{H}_{6}+\mathrm{H}_{2} \longrightarrow \mathrm{C}_{3} \mathrm{H}_{8}$

$\mathrm{CH}_{2}+\mathrm{C}_{3} \mathrm{H}_{6} \longrightarrow \mathrm{C}_{4} \mathrm{H}_{8} \quad$ etc

For instance, confined polymerization of the hydrocarbon building block using selectivity catalyst, yields gasoline

$\left(\mathrm{C}_{5}\right.$ to $\left.\mathrm{C}_{10}\right)$, kerosene $\left(\mathrm{C}_{10}\right.$ to $\left.\mathrm{C}_{16}\right)$ or diesel $\left(\mathrm{C}_{14}\right.$ to $\left.\mathrm{C}_{20}\right)$

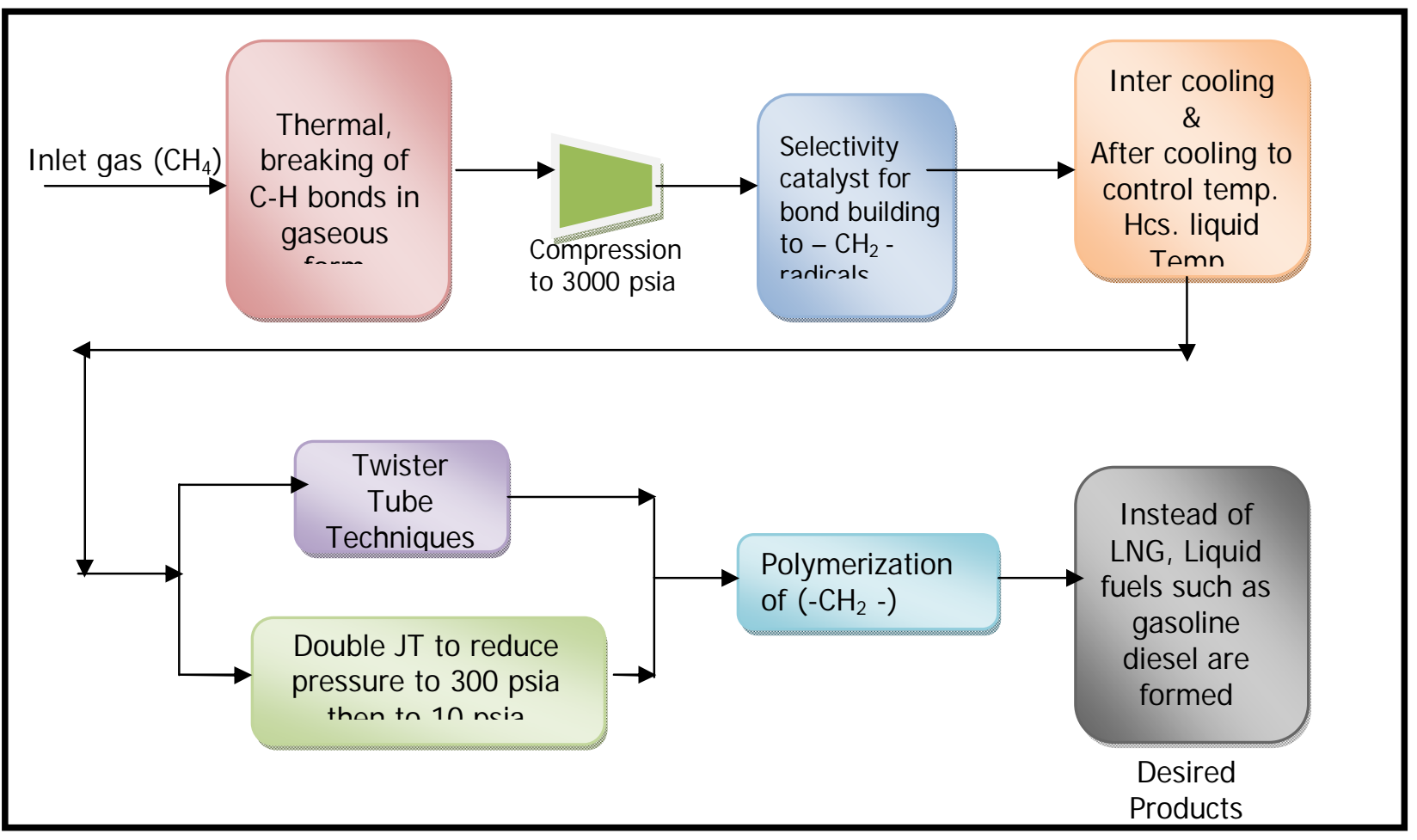

Figure 33: Proposed Thermo - Physio - Chemical Process 
The Twister Tube Gas Processing Technology (Schinkelshock and Epson, 2006) which operates at supersonic velocity, in combination of known physical processes, aero- dynamics, thermo-dynamics and fluid dynamics in a compact tubular device.

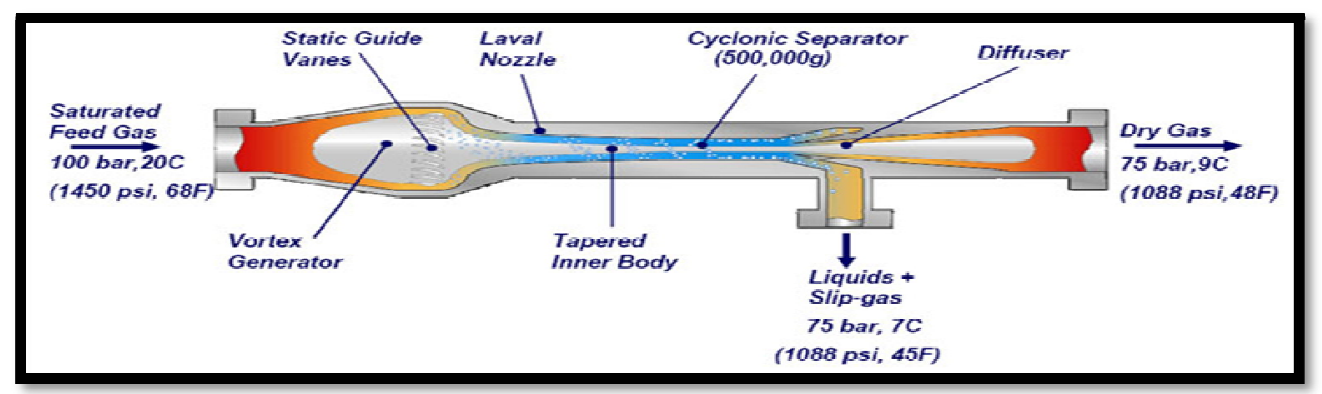

Figure 34: A Cross-Section View of the Tube Shows Separation Elements. Source: Adapted from Arash, 2016; Betting and Marco, 2007

Conventionally, Twister Tube is a novel gas dew pointing device in which natural gas flows through a separation section at supersonic velocity extracting water and hydrocarbon liquids (Shell, Nigeria). Due to the low static pressure and the resulting low temperature at these supersonic conditions, liquid formation occurs inside the Twister. Liquid droplets in the submicron range are separated from the gas stream in the Twister tube due to extremely high rotational force ( $>$ 500, 000 times gravitational acceleration) (Janssen and Betting, 2006). Analogically, the same procedure is applied to gaseous radicals of hydrocarbon building blocks $\left(-\mathrm{CH}_{2}-\right)$ reduced to hydrocarbons liquid temperature to polymerize to specific products such as gasoline, kerosene or diesel.

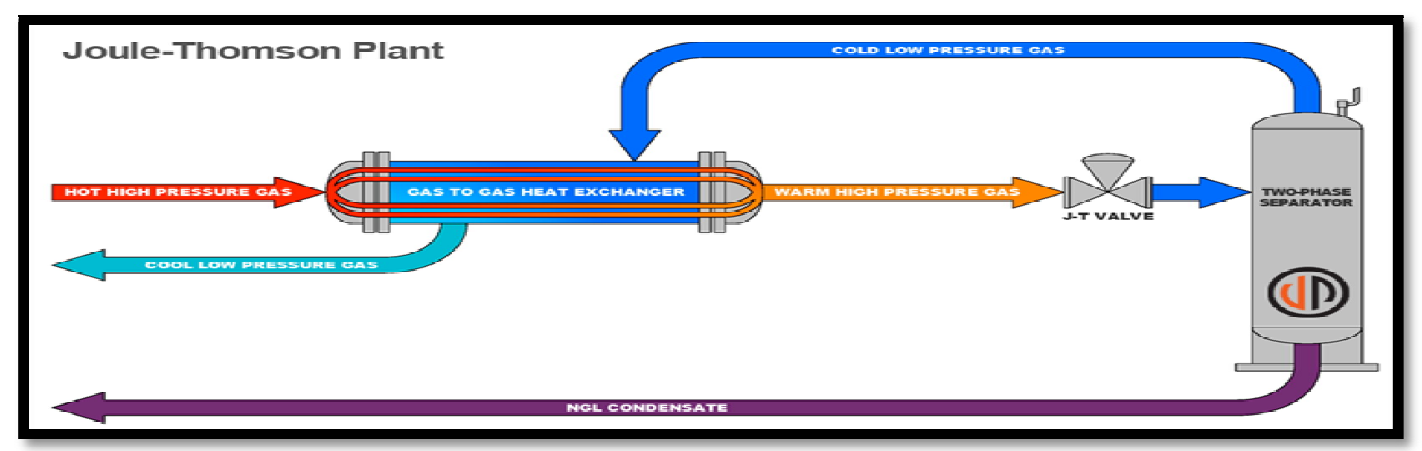

Figure 35: Joule-Thomson Valve Liquefaction Process

Source: Adapted From the Images of the Joule-Thomson Valve

\section{Material}

Table 6 shows the typical representative composition of the flared associated stranded natural gas stream in Nigeria, obtained from statistical analysis of 36 flare streams, selected from 150 flare line data samples. And table 7 contains the average operational parameters of the Nigeria flare gas stream (Ekejiuba, 2017). While table 8 shows the typical PVT conditions of Natural Gas (methane) at different operating locations

\begin{tabular}{|c|c|}
\hline Component & Mole \% \\
\hline Methane & 78.5375 \\
\hline Ethane & 7.7880 \\
\hline Propane & 5.9625 \\
\hline i-butane & 1.4842 \\
\hline n-butane & 1.8882 \\
\hline i-pentane & 0.6964 \\
\hline n-pentane & 0.4982 \\
\hline Hexane plus & 0.7550 \\
\hline Nitrogen & 0.1729 \\
\hline Carbon dioxide & 2.0105 \\
\hline Other undesirables & 0.2066 \\
\hline & 100.0000 \\
\hline
\end{tabular}

Table 6: A Typical Representative Composition of Flare Associated

Stranded Natural Gas in Nigeria

Source: Adapted from Ekejiuba, 2017 


\begin{tabular}{|c|c|c|}
\hline Parameter & Range & Value for the Study \\
\hline Gas Gravity (air) & 0.607 to 0.996 & 0.755 \\
\hline Flow rate MMscfd & 5 to 63 & 20 \\
\hline Pressure Psig & 7 to 75 & 10 \\
\hline Pressure & 21.7 to 89.7 & 25 \\
\hline Temperature F & 60 to 115 & 80 \\
\hline Base Temperature During Analysis & - & $60 \circ \mathrm{F}$ \\
\hline Base Pressure During Analysis & - & $14.7 \mathrm{psia}$ \\
\hline
\end{tabular}

Table 7: Flare Conditions of the Associated Stranded Natural Gas in Nigeria Source: Adapted from Ekejiuba, 2017

\begin{tabular}{|c|c|c|c|}
\hline Operation / location & Temperature ${ }^{\circ} \mathrm{F}$ & Pressure psi & Volume $\mathrm{ft}^{3}$ \\
\hline Reservoir & 160 & 4000 & 1 \\
\hline $\begin{array}{l}\text { Wellhead (atmospheric } \\
\text { condition) }\end{array}$ & 60 & 14.7 & 238 \\
\hline Pipeline & 60 & 1000 & 3 (i.e.79.33 :1) \\
\hline CNG & 70 & 3,600 & 1.19 (i.e.200 :1) \\
\hline NGH & $-4\left(-20^{\circ} \mathrm{C}\right)$ & 870 & 1.6 (i.e. $150: 1$ ) \\
\hline LNG & $-260\left(-162{ }^{\circ} \mathrm{C}\right)$ & 580 (40 bar) & 0.4 (i.e.600 :1) \\
\hline FT-GTL & $\begin{array}{c}\text { LTFT } 428 \text { to } 518 \text { or }\left(220^{\circ} \mathrm{C}\right. \\
\left.\text { to } 270^{\circ} \mathrm{C}\right)\end{array}$ & 1.22 & 0.13 (i.e.1781 :1) \\
\hline FT-GTL & $\begin{array}{c}\text { HTFT } 572 \text { to } 662 \text { or }\left(300^{\circ} \mathrm{C}\right. \\
\left.\text { to } 350^{\circ} \mathrm{C}\right)\end{array}$ & 1.02 & 0.13 (i.e.1781 :1) \\
\hline DME/ Methanol & $\begin{array}{c}\text { Cracking at between } 599 \text { to } \\
1,346\left(315^{\circ} \mathrm{C} \text { to } 7300^{\circ} \mathrm{C}\right)\end{array}$ & $\begin{array}{c}\text { Between 14.7 (1atm) } \\
\text { to } 1,000 \mathrm{psi} \\
\end{array}$ & 0.13 (i.e.1781:1) \\
\hline $\begin{array}{c}\text { Proposed New Direct } \\
\text { GTL }\end{array}$ & 60 & 14.7 & $\begin{array}{c}0.13 \text { to } 0.4 \text { (i.e.1781 :1 } \\
\text { to } 600: 1 \text { ) }\end{array}$ \\
\hline
\end{tabular}

Table 8: Typical PVT Conditions of Natural Gas (Methane) at Different Operating Locations

\section{Proposed Model Application:}

Conventionally, processing the flared associated stranded natural gas to remove undesirable components such as, carbon dioxide, hydrogen sulfide and other sulfur components, and nitrogen is termed sweetening (Campbell, 1976). Figure 36, is the proposed design process layout for the overall sweetening of the associated flared natural gas and the details of the proposed four alternative routes for gasoline, kerosene and diesel production from the flare line.

Generally, the temperature required to condense natural gas depends on its precise composition, but it is typically between $-120^{\circ} \mathrm{C}$ and $-170{ }^{\circ} \mathrm{C}\left(-184{ }^{\circ} \mathrm{F}\right.$ and $\left.-274{ }^{\circ} \mathrm{F}\right)$, (Sarthak Sinha, 2016). The feed gas is obtained from the flare line at 21.7 to 89.7 psia and 60 to $115 \mathrm{oF}$. After removal of entrained solids and liquids, the gas is compressed to about 500 psia and purified by physical adsorption, by passing it through a molecular sieves dryer to remove carbon dioxide, water vapor, and hydrogen sulfide or it is entered into an amine process where hydrogen sulfide and carbon dioxide are removed, while water vapor is removed down to $-100 \circ \mathrm{F}$ dew point by a combination of glycol injection and alumina bed dryers and diethylene glycol can be injected to protect from hydrates at a chiller temperature of minus $23{ }^{\circ} \mathrm{C}$ (Ikoku, 1980). For the Joule-Thomson expansion the gas is further compressed to 3,000 psia in an electrically driven two-stage reciprocating compressor, using both intercooling and aftercooling to control the gas temperature. After passing through the heat exchanger, the gas undergoes a double Joule-Thomson expansion, first to 300 psia and finally to 10 psia to obtain the LNG. And for the classic propane-ethylene-methane cascade cycle each refrigerant fluid is vaporized at a different pressure, selected to give the appropriate temperature for the required heat transfer duty. Precisely, the dry gas from the purification unit is cooled in two stages for the removal of pentanes and heavier hydrocarbons. Next the gas is totally condensed in the three-stage ethylene chiller at about ( $-80 \mathrm{oF}$ to $-142 \circ \mathrm{F})$ at 490 psia, and furthermore the LNG is cooled in three methane feed chillers and then expanded in a flash drum which cools it to a final temperature of $-259 \circ \mathrm{F}$ and $5 \mathrm{psig}$ 


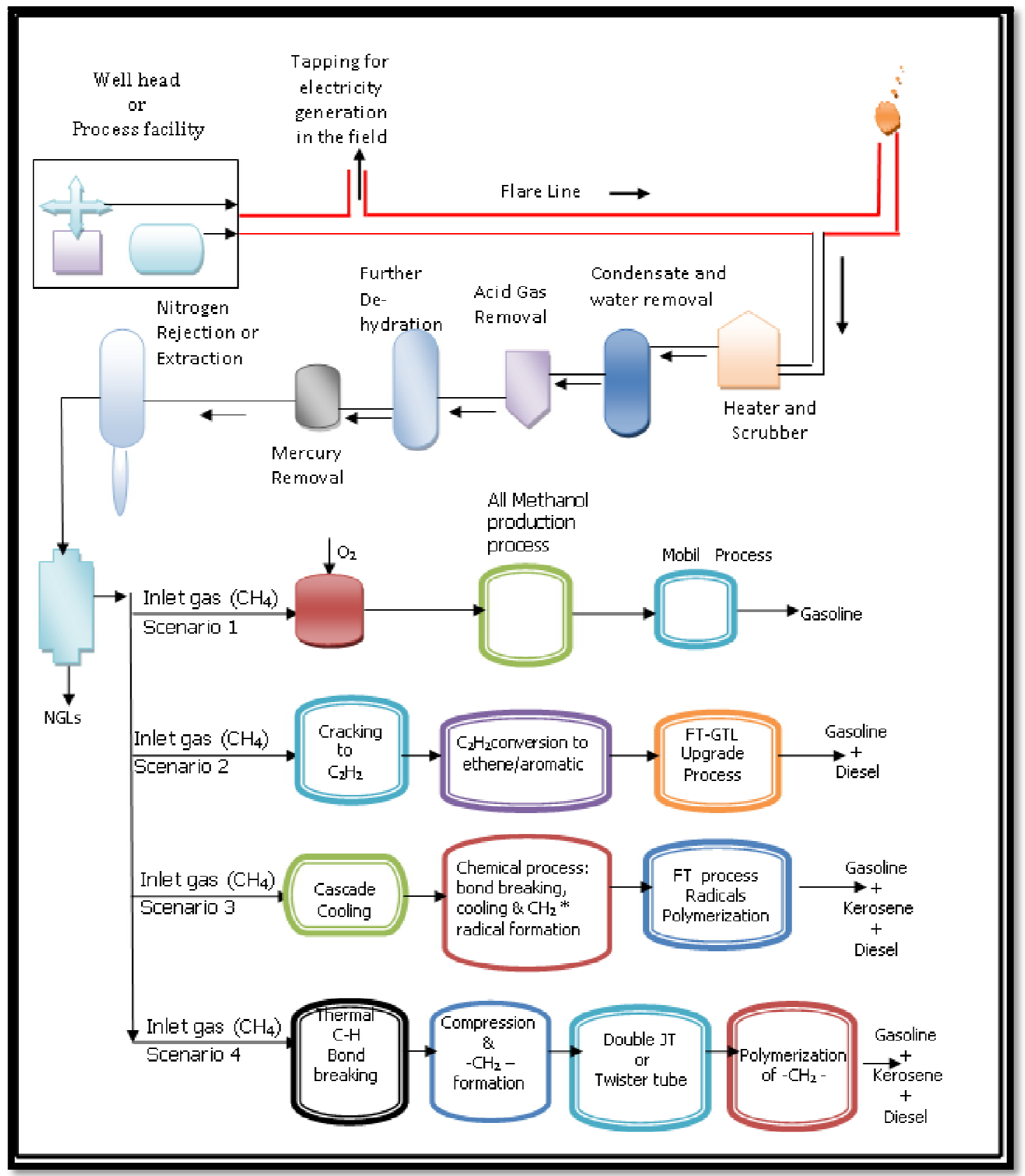

Figure 36: Process Layout for the proposed four New Real-Time Gases-to -Liquid Production Routes

\section{Results and Discussion}

7.1. The Estimated Real-Time Methane Liquid Products

(A)The total percentage of the methane hydrocarbon in the flare stream (table 4) is $78.5375 \%$, which implies that, for the $20,000,000$ scfd flare line, the actual methane hydrocarbon flare quantity is $15,707,500$ scfd (i.e. $20,000,000 \mathrm{x}$ $0.785375)$.

On the average, GTL converts every 10,000-cuft of natural gas (methane) to 1 barrel (42 US gallons) or (160 liters) of liquid fuel.

$1 \mathrm{bbl}=5.615$ cubic feet $\left(\mathrm{ft}^{3}\right)$ of liquid and also $1 \mathrm{bbl}=0.159$ cubic meters $\left(\mathrm{m}^{3}\right)$ of liquid, table 9 .

\begin{tabular}{|c|c|c|c|c|c|}
\hline Component & $\begin{array}{c}\text { Fractional } \\
\text { Composition }\end{array}$ & $\begin{array}{c}\text { Daily } \\
\text { MMscf }\end{array}$ & $\begin{array}{c}\text { Daily Liquid } \\
\text { Equivalent: } \\
\text { Barrels }\end{array}$ & $\begin{array}{c}\text { Daily Liquid } \\
\text { Equivalent: } \\
\text { Cubic Feet }\end{array}$ & $\begin{array}{c}\text { Daily Liquid } \\
\text { Equivalent: } \\
\text { Cubic Meters }\end{array}$ \\
\hline Methane & 0.785375 & 15.707500 & $1,570.7500$ & $8,819.76125$ & 249.74925 \\
\hline
\end{tabular}

Table 9: Real-Time Daily Flare Stream Methane Liquid Quantities for 20 Mm SCFD. Flow Rate

For this investigation, the target liquids are either gasoline, kerosene, diesel or combination of any two of them or combination of the three. 
(a) $15,707,500 / 200=78,537.5 \mathrm{cu}$. $\mathrm{ft}$ of CNG

(b) $15,707,500 / 600=26,179.167$ cu.ft of LNG

(c) $15,707,500 / 1,781=8,819.483 \mathrm{cu}$. ft of GTL

Since, from the fact that GTL converts every 10,000-cuft of natural gas (methane) to 1 barrel, and $1 \mathrm{bbl}=5.615$ cubic feet

( $\mathrm{ft}^{3}$ ) of liquid, it follows that 10,000-cuft / 5.615 cubic feet =1780.94 approximately 1781 .

(d) 1,570.7500 barrels of synfuels daily production is equivalent to 65,971.5 gallons or 251,320 litres.

(B) The possible electricity generation daily from the $20 \%$ released reaction heat is estimated as follows:

$15,707,500 \mathrm{scf} / \mathrm{d}$ x $0.2=3,141,500 \mathrm{scf} / \mathrm{d}$

Dividing by 24 implies $\quad 3,141,500 / 24=130,895.833 \mathrm{scf} / \mathrm{h}$

For a Gas turbine generator with 30\% efficiency and applying the gas conversion assumed calorific value of $1000 \mathrm{Btu} / \mathrm{scf}$.

The heat rate becomes $3412 / 0.3=11,373.33 \mathrm{Btu} / \mathrm{kWh}$.

Using the relation

Power Output (kW) $=\{$ Fuel Burned (scf/ hr) x Heating Value Btu/scf $\} /$ Heat rate Btu/ kWh

$=\{130,895.833 \times 1000 \mathrm{Btu} / \mathrm{scf}\}\{11,373.33 \mathrm{Btu} / \mathrm{kWh}\}$

$=11,509 \mathrm{~kW}$

Approximately 11.5 MW

\section{Conclusion}

Methane, the simplest alkane hydrocarbon gas is colorless, odorless and exhibits very low chemical reactivity because it has the strongest bonds among hydrocarbons. It is obtainable from various sources, such as natural gas, naturally occurring gas hydrates, organic wastes from biomass including manure, municipal solid waste, landfills, hydrocarbon liquids, coal seams et cetera. The two categories of methane gas liquefaction processes are (a) the transitional processes, which are aimed at reducing the gaseous volume for transportation convenience such as the mechanical refrigeration, the turbo-expander cycle and the joule-thomson cycle (b) the permanent processes in which chemical transformation of the gas molecules occur simultaneously with volume reduction.

Gas-to-Liquid (GTL) technology is a chemical conversion process which is designed to convert gaseous methane to synthetic liquid fuels such as gasoline, kerosene, diesel etc. and chemical liquids such as methanol, ammonia, dimethylether, ethanol et cetera. The two distinct GTL production routes are (a) the indirect route which first, catalytically or non-catalytically convert methane to syngas (a mixture of carbon monoxide and hydrogen) and subsequently convert the syngas to liquid products with the help of selectivity catalysts (b) the direct route which involves a single-step catalytic chemical conversion of gaseous methane to liquid products.

This investigation presents four proposed direct GTL models based on the synergy/ synthesis (i.e. combined application or effects) of various scientific fundamentals.

(a) direct methanol production by controlled oxidation of methane (b) direct thermo-chemical generation of olefin or aromatic hydrocarbon from methane (c) direct physio-chemical generation of radicals $\left(\mathrm{CH}_{3} *, \mathrm{CH}_{2}{ }^{*}, \mathrm{H}^{*}\right)$ and $\mathrm{H}_{2}$ from methane and (d) direct thermo- physio -chemical generation of hydrocarbon building block (- $\mathrm{CH}_{2}$-) from methane.

The study estimates that 1,570.7500 barrels (8,819.483 cu. ft.) equivalent to 65,971.5 gallons or 251,320 litres of synfuel products plus 11.5 MW electricity could be obtainable daily from a 20 MMscfd flare line made up of 78.5375\% methane.

\section{References}

i. Arash, E., 2016. Supersonic Separation of Natural Gas Liquids by Twister Technology. Chemical Engineering Transactions, Vol. 52.www.aidic.it>cet(accessed 21:09:17).

ii. Atkins, P.W., 1979. Physical Chemistry. ELBS edition. University Press, Oxford by Eric Buckley. p.950.

iii. Bamkole, T.O., Ogunkoya, L., 1978. Introductory Organic Chemistry. Second Edition. Daystar Press, Ibadan. pp. 64, 137, 189.

iv. Betting, M., Epsom, H., 2007. Supersonic Separator gains Market acceptance. World Oil, April 2007 Issue, pp.197200. https:/ / www.scribd.com>document>su... (accessed 21:09:17).

v. Block, L. D., Linkous, C., Muradov, N., 1995. Production of Hydrogen by Thermo catalytic Cracking of Natural Gas. Task 4 Report for the US Department of Energy. https:// www.osti.gov/ scitect/ servlets/purl/ 564093 (accessed $15: 10: 18)$

vi. Brown, W.H, Foote, C. S., Iverson, B.L., 2005. Organic Chemistry, Fourth Edition, Thomson Books/ Coll Belmont, United States. pp.216, 239, 279, 304-306, 368,567, 603, 953.

vii. Campbell, J.M., 1976. Gas Conditioning and Processing Volume 2. Campbell Petroleum Series, Oklahoma, U.S.A. p. 222.

viii. Cui, Z., 2014. When is the Future for Synthetic Fuel? Standford University Large.standfor.edu $>$ courses $>$ cui1.

ix. Ebbing, D.D., Wentworth, R.A.D, Birk, J. P., 1995. Introductory Chemistry. Houghton Mifflin Company. pp. 350-373.

x. Ekejiuba, A. I. B., 2017. Real-Time Monetization of the Flare Associated Stranded Natural Gas in Nigeria: Quantitative Analysis and Qualitative Values. The International Journal of Science \& Technology, Vol. 5 Issue 8, p. 96.

xi. Encyclopaedia Britannica. Methane (accessed 02:09:18)

xii. Femi Asu. Nigeria among 10 Cheapest places to buy Petrol-Report. https:// punching.com/nigeria-among-10cheapest-places-to-buy-petrol.

xiii. Foster, J.M., 2012. From Methane to Plastic to Methane, Without Waste (accessed 04:09:18).

xiv. Global Petrol Prices. https:// www.globalpetrolprices.com/ benchmark/ (accessed 15:09:18) 
xv. Henry Hub. Natural Gas Prices. https:// markets.businessinsider.com/commodities/natural-gas-prices (accessed 15:09:18)

xvi. Heys, H. L., 1980. Physical Chemistry, Fifth Edition, Harrap London. pp. 244-251, 363.

xvii. Ikoku, C. U., 1980. Natural Gas Engineering: A Systems Approach. Pennwell Books Tulsa, Oklahoma USA. pp. 9-19, 27-40.

xviii. Janssen, J. W. F., Betting, M., 2006. Combined Test with the Improved Performance Twister ${ }^{\mathrm{TM}}$ Supersonic Separator and the Gasunie Cyclone Separator, Journal of the Nigerian Gas Association. p. 19.

xix. Judith C. Perez, n.d. Super Critical Fluids General Chemistry, Arizona State University ～（accessed 18:09:18)

xx. Kurevija, T., Kukulj, N., Rajkovic, D., 2007. Global Prospects of Synthetic Diesel Fuel Produced from Hydrocarbon Resources in Oil and Gas Exporting Countries. https:/ / hrcak.srce.hr/ file/ 30195. (accessed 19:10:18)

xxi. Nagpal, S., 2017. Liquefaction of Gas and Critical Temperature-Chemistry, Class II, States of Matter Classnotes. Classnotes.org.in>liquefaction (accessed 18:10:17)

xxii. Natural GasPrices/ Oil prices. https:/ / oilprice.com/ Energy/ Natural-Gas (accessed 15:09:18)

xxiii. Ofoegbu, D.I., 2015. Gas Flaring in Nigeria: A Story for the Gods. The Nigerian Voice Newspaper. thenigerianvoice.com, (accessed 24:05:17).

xxiv. Power, Environmental Energy Research Institute (PEERI)http://www.peeri.org/industrial/liquid.htm(accessed 06:10:17).

xxv. Perry, R.H., 1985. Perry's Chemical Engineers' Handbook. 6th Ed. New York, McGraw-Hill International Book Company.

xxvi. $\quad$ Physics Tutorial Online. www.Physics Tutorials.org (accessed 03:5:18)

xxvii. Sarthak Sinha, 2016. What is the difference between compressed natural gas and liquefied natural gas related to fuel. https:/ / www.quora.com/ What-is-the-difference- between-compressed-natural-gas-and-liquefied-natural-gasrelated-to-fuel. (accessed 18:04:18)

xxviii. Schinkelshock, P., Epsom, H., 2006. Supersonic Gas Conditioning-Low Pressure Drop TWISTER ${ }^{\mathrm{TM}}$ for NGL Recovery, Offshore Technology Conference, Houston, Texas, U.S.A. (accessed 18:10:18)

xxix. Selectivity of Catalyst and its Activity/ Catalyst Chemical Reaction. https:/ / byjus.com/ chemistry/ activity-selectivityof-catalyst/ (accessed 17:10:18)

xxx. Shah, P., Durr, KBR., 2007. Monetizing Stranded Gas. Emerging and Peripheral Technologies, Petroleum Engineering Handbook, Volume VI, Society of Petroleum Engineers, Richardson, TX. USA. pp. VI-359 to VI-361.

xxxi. Shell, Nigeria., 2009. Shell, Twister Announce New System Startup in Nigeria. Pipeline \& Journal, June 2009 Vol.236 No.6. https:// pgjonline.com>2009|06|18>she... (accessed 21:09:17).

xxxii. Sherman, S.J., Sherman, A., 1999. Essential Concepts of Chemistry. Houghton Mifflin Company. Boston. p. 285.

xxxiii. Silva, C.A., Miranda, P.E.V., 2016. Proposition of a Mechanism for the Electrochemical Oxidative Coupling of Methane. www.scielo.br/ pdf/ rmat/ v21n4/ 1517-7076-rmat-21-04-00001.pdf (accessed 17:09:18)

xxxiv. Timberlake, K.C., 2006. An Introduction to General, Organic and Biological Chemistry. Ninth Edition Person Benjamin Cummings. p. 373.

xxxv. Unpublished Final Year project in Petroleum Engineering Department Federal University of Technology, 2014

xxxvi. Wikipedia. Diesel fuel. https:/ / en.wikipedia.org/ wiki/ Diesel_fuel(accessed 16:09:18)

xxxvii. Wikipedia. Fuel. https:// en.wikipedia.org>्रuel (assessed, 24:05:17)

xxxviii. Wikipedia. Gasoline. https:/ / en.wikipedia.org/ wiki/ Gasoline (accessed 16:09:18)

xxxix. Wikipedia. Kerosene. https:/ / en.wikipedia.org/ wiki/ Kerosene (accessed 16:09:18)

xl. Wikipedia. Methane. (accessed 02:09:18)

xli. Wikipedia. Synthetic Fuel. https:// en.wikipedia.org>wiki.synthetic - fuel(assessed, 24:05:17).

xlii. Images of Application of the Joule-Thomsom Effect. (accessed 12:10:18)

xliii. Images of the Compressed Natural Gas Process (accessed 05:05:18)

xliv. Images of the GTL market (accessed 14:10:18)

xlv. Images of the GTL processes (accessed 16:10:17)

xlvi. Images of the Hydrocarbon Chemistry (accessed 02:09:18)

xlvii. Images of the Hydrocarbon Components (accessed 02:09:18)

xlviii. Images of the Methane. (accessed 02:09:18)

xlix. Images of natural gas liquids recovery units. (accessed 7:09:17)

1. Images of syngas to alkanes (accessed 22:8:18)

li. Images of the Solid, liquid and gas (accessed 2:10:18)

lii. Images of the Standard Cascade liquefaction (accessed 05:05:18)

liii. Images of tetrahedral methane. (accessed 04:09:18)

liv. Images of the Turbo-expander. (accessed 12:10:18)

lv. Images of transition metal catalytic surface (accessed 17:10:18)

lvi. Images of the uses and properties of Liquid and gaseous fuel (accessed 2:10:18). 